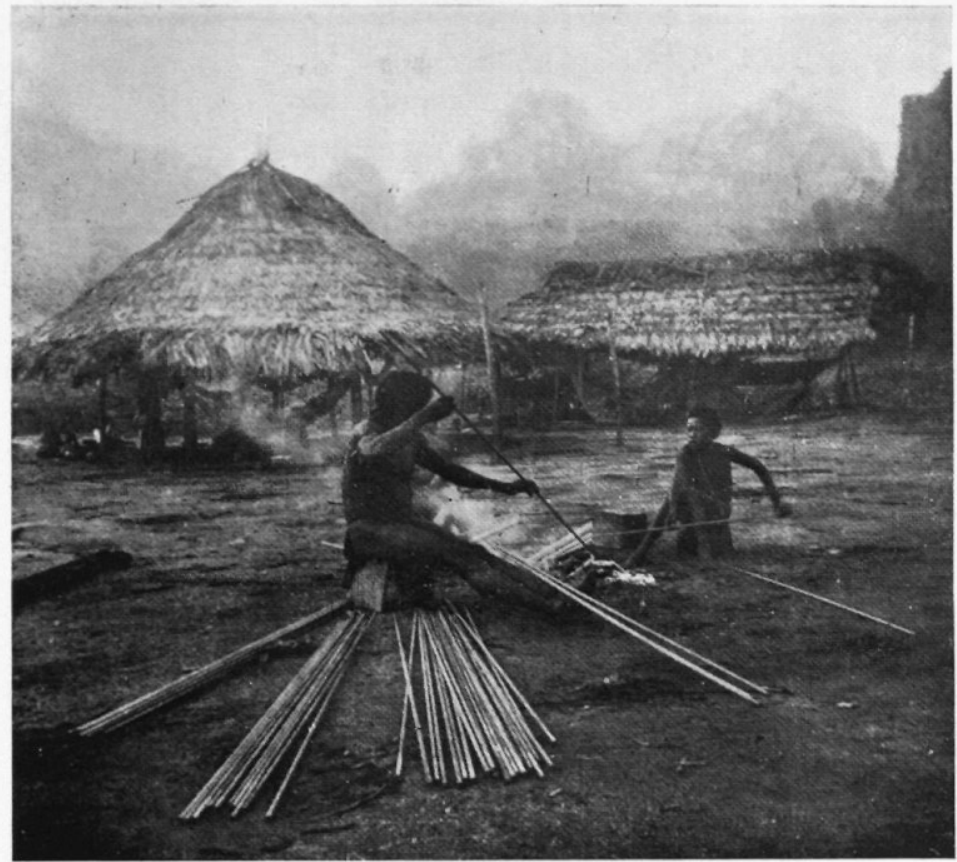

Foto 1. Oayana-dorp Taponte 15 Juli 1937 's ochtends vroeg; mannen maken pijlen

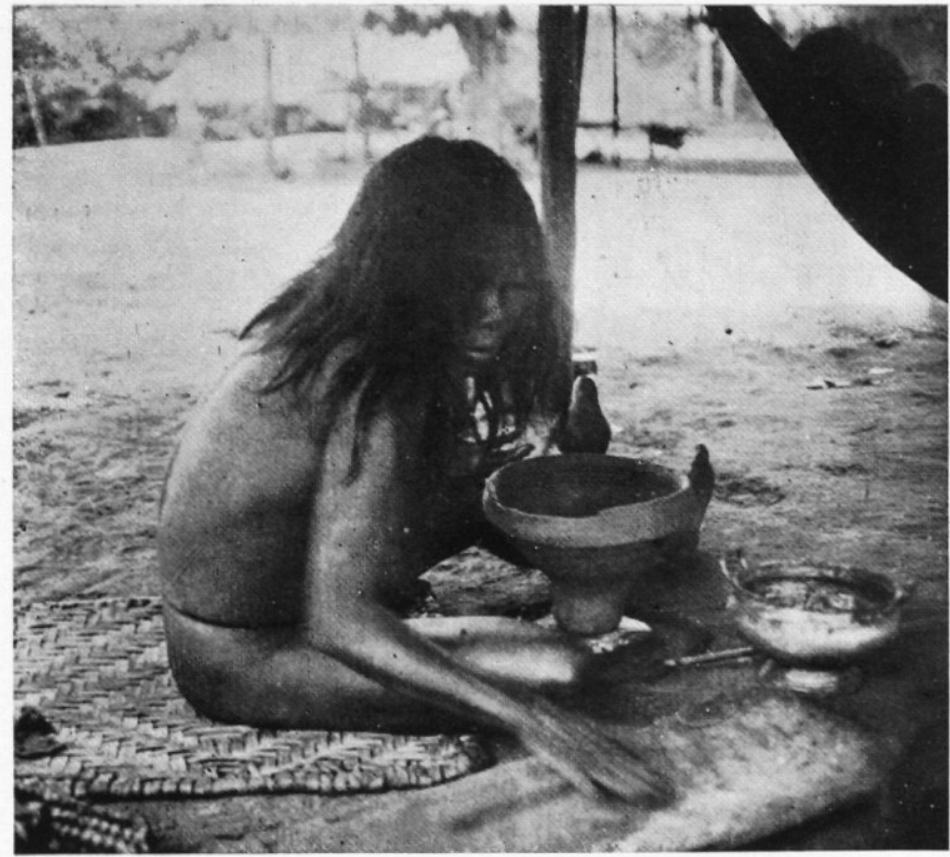

Foto 2. Oayana-dorp Taponte 13 Juli 1937; de vrouw Kenelupke kneedt potten. 


\title{
DE OAYANA-INDIANEN.
}

\author{
DOOR \\ C. H. DE GOEJE. \\ (Met 11 foto's en muziek in den tekst.)
}

\section{Inleiding.}

$\S 1$. Dit opstel bevat de uitkomsten van een reis naar Suriname in 1937, voor wat de volkenkunde der Oayana-Indianen betreft. ${ }^{1}$ ) Bij aankomst te Paramaribo vond ik daar den hoofdman Apetina van de Paloemeu met reisgezelschap, en was twee weken met hen samen. Vervolgens ben ik met de grensexpeditie de Marowijne opgevaren en heb bijna vier maanden gewoond op het dorp van den hoofdman Taponte $(\dagger 1938)$ aan de Litani (zie foto's 1-4, 7-10).

De materieele cultuur van dit volk was reeds in groote trekken bekend door de mededeelingen van vroegere onderzoekers. Omtrent sociale verhoudingen en dagelijksch leven waren wij eenigszins ingelicht door het oppervlakkige, maar overigens betrouwbare werk van $\mathrm{H}$. Coudreau $\left.(\mathrm{C})^{2}\right)$, den eenigen die langen tijd achtereen bij Oayana's had vertoefd. Van hun geestelijke cultuur was echter bijna niets opgeteekend en met het onderzoek der taal was nog slechts een begin gemaakt.

1) Reeds verschenen: $1^{\circ}$ populair opstel „Bij primitieve volken”. De Gids. Amsterdam, Juni $1939 ; 2^{\circ}$ over de Negers van Suriname „Aanteekeningen over het geestelijk leven en de samenleving der Djoeka's (Aukaner Boschnegers) in Suriname, door W. F. van Lier, met een inleiding en aanvullende gegevens van C. H. de Goeje, Bijdr. t. d. Taal-, Land- en Volkenkunde van Ned.-Indië, deel 99, 's-Gravenhage 1940. In bewerking: $3^{\circ}$ Etudes linguistiques caribes II (Oayana, Tliometesem, Wama, Kaliña, met gegevens van mevrouw L. StahelJordi, Prof. Dr. G. Stahel, W. Ahlbrinck, Dr. D. C. Geijskes, C. C. Käyser en A. Ph. Penard); $4^{\circ}$ Inwijding en mythen der volken van Guyana en omgeving (waarbij nieuwe gegevens van Arawakken en Kaliña's).

2) Voor deze afkortingen, zie lijst van Literatuur.

Spelwijze der inlandsche woorden : $\underline{e}$ als e in bek; $\ddot{e}$ als u in lust; a als e in vader; $\ddot{i}$ tusschen $\mathrm{i}$ en $\ddot{i}$; $\ddot{o}$ als eu in neus; $u$ als oe in boek; $\ddot{u}$ als $u$ in ruw ; $\check{s}$ als sj.

De muziek in dit opstel, is met behulp van een stemfluitje op de werkelijke toonhoogte opgeteekend. 
Allereerst moest ik die taal verder onderzoeken en het gevondene mij eigen maken, om met de menschen te kunnen spreken. Zonder geschreven teksten en zonder tolk is dat niet gemakkelijk, en vóór ik de taal geheel meester was, liep mijn verblijf bij de Oayana's ten einde. Daardoor zijn het slechts fragmenten van volkenkunde die ik hier heb aan te bieden, doch door er mededeelingen van vroegere en latere onderzoekers bij te voegen, is het toch eenigermate een geheel geworden. Voorts kwamen bij vergelijken met naburige volken eenige belangrijke dingen aan het licht, wat hier en daar in den tekst en in noten is vermeld.

$\S$ 2. De Oayana's of Roekoejana's ${ }^{1}$ ) behooren ten volle tot de autochtone bevolking van Amerika. De stam telt thans ongeveer 600 zielen, verdeeld over omstreeks 20 dorpen, aan weerszijden van het Toemoekhoemak-gebergte aan de Litani, Paloemeu-Tapanahoni, Jari en Paroe met zijtakken. ${ }^{2}$ ).

Hun taal is een der omstreeks 40 talen der karibische groep en in die groep zijn hun naaste verwanten de Chayma's, Cumanagoto's en Tamanaco's, die vroeger nabij de beneden-Orinoco woonden. ${ }^{3}$ ) Volkenkundig hebben de Oayana's zeer veel gemeen met hun zuidelijke buren, de eveneens karibische Aparai's. Onderlinge vergelijking der verschillende karibische talen voerde mij tot de slotsom, dat het niet zoo heel lang geleden kan zijn, dat ze één taal vormden, stel een paar duizend jaar voor Christus. Er is geen reden om aan te nemen, dat de voorvaderen toen elders woonden, dan in het land waar thans de meesten der nakomelingen wonen, d.i. in Guyana. ${ }^{4}$ ) Het eenige gegeven omtrent een nog oudere geschiedenis is, dat er belangrijke over-

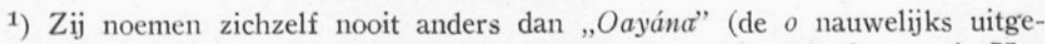
sproken; men kan ook schrijven Wajana of Oajana, Fransch Ouayana). Hoe men aan den naam Roekoejana (reeds in de 18e eeuw) is gekomen, kan ik niet zeggen. Allicht niet naar $(u) r u k u$, de roode huidverf van Bixa Orellana, wijl alle stammen zich met die verf inwrijven, terwijl bovendien dit woord tot een Tupi-taal behoort, de uitgang -yana daarentegen karibisch is.

2) Vroerere schattingen: 1787 (Leblond) 32 dorpen, 4000 (?) zielen; 1890 (Coudreau) 36 d., 800 à 1600 z.; 1907 (de Goeje) 23 d., 1000 z.

3) Aldaar woonde ook het volk der Guayana's, welker naam, overgegaan op het geheele land „Guayana” of Guyana, naar Spaansche uitspraak vrijwel hetzelfde klinkt als „Oayána”. Ongelukkig zijn er maar luttele gegevens van dit volk opgeteekend; het sprak echter een karibische taal; analyse van de enkele woorden dier taal, die bewaard zijn, zie $8 \mathrm{G}$.

4) K. von den Steinen meende, dat het stamland der Kariben ten Zuiden der Amazone-rivier lag, en dat de Bakairi's en andere volkjes aldaar, die een karibische taal spreken, waren achtergebleven, toen de overigen naar het Noorden, naar Guyana trokken. $Z$ ijn bewijsgronden lijken mij te zwak. 


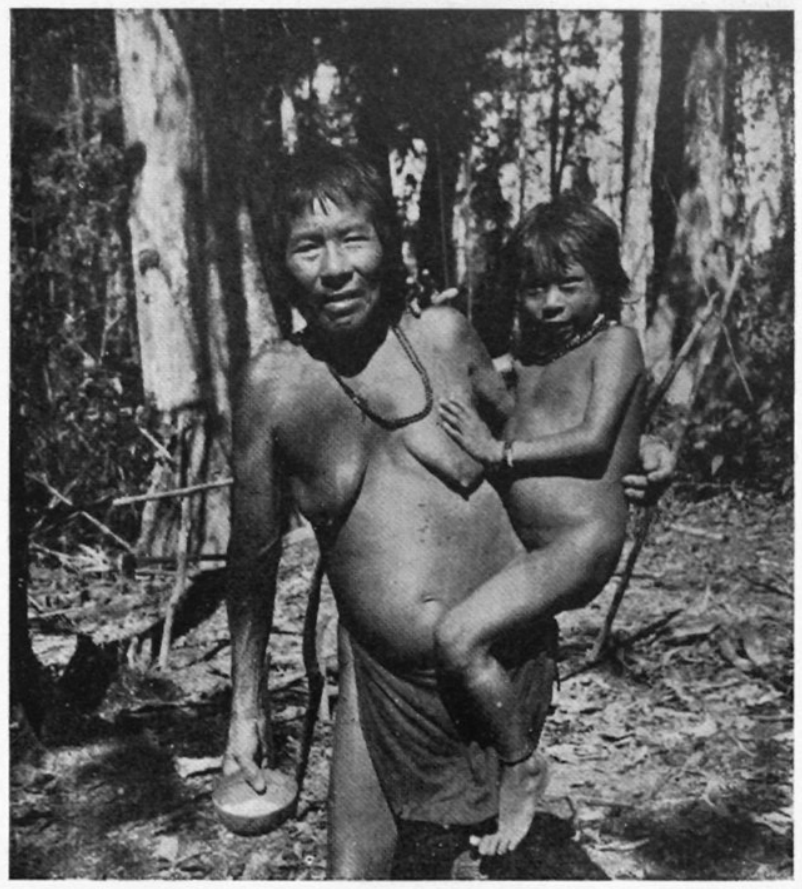

Foto 3. Oayana-dorp Taponte 16 Aug. 1937: de kuni (oude vrouw) Mapupan met kleindochterje Kulena.

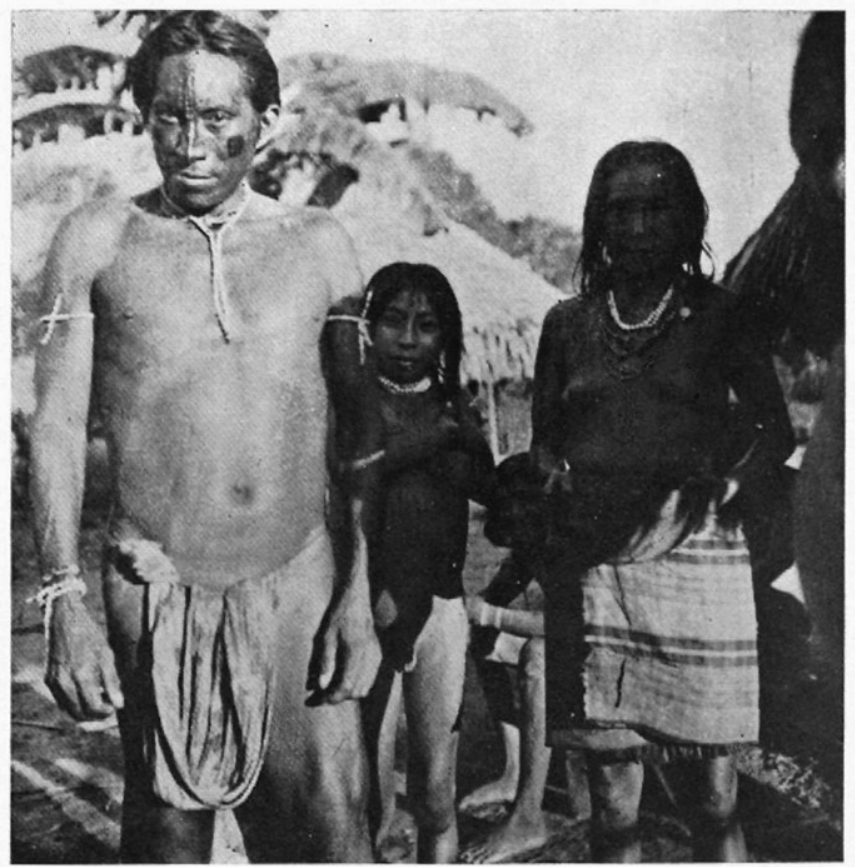

Foto 4. Oayana-dorp Taponte 12 Juli 1937; EmerillonIndianen op bezoek. 


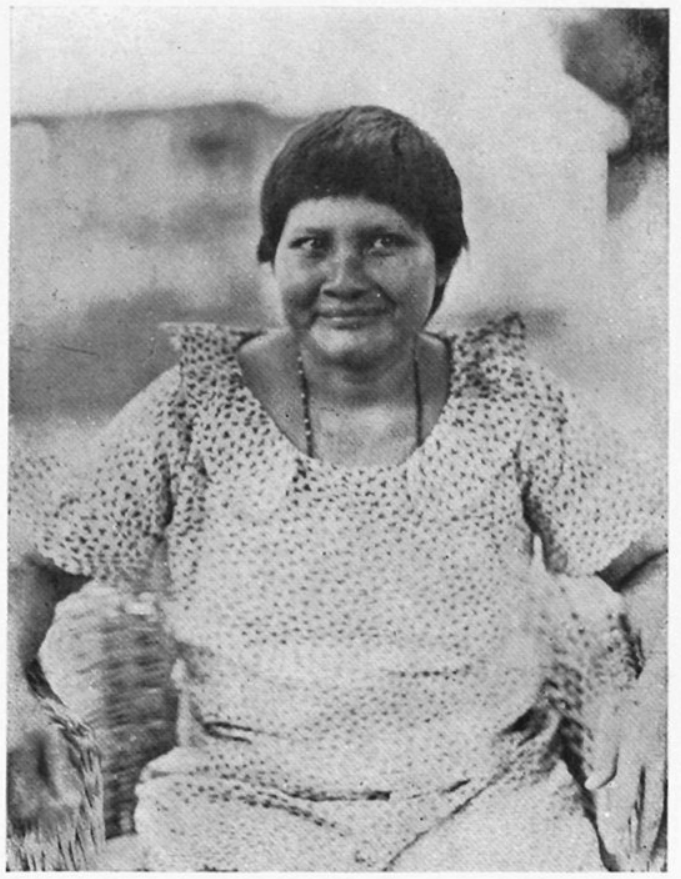

Foto 5. De vrouw Malawni, vermoedelijk de laatst overlevende van den stam der wilde Oayarikoelés of Thiometesem's, en gestorven 1938. Foto genomen door G. Stahel te Paramaribo, Juli 1937.

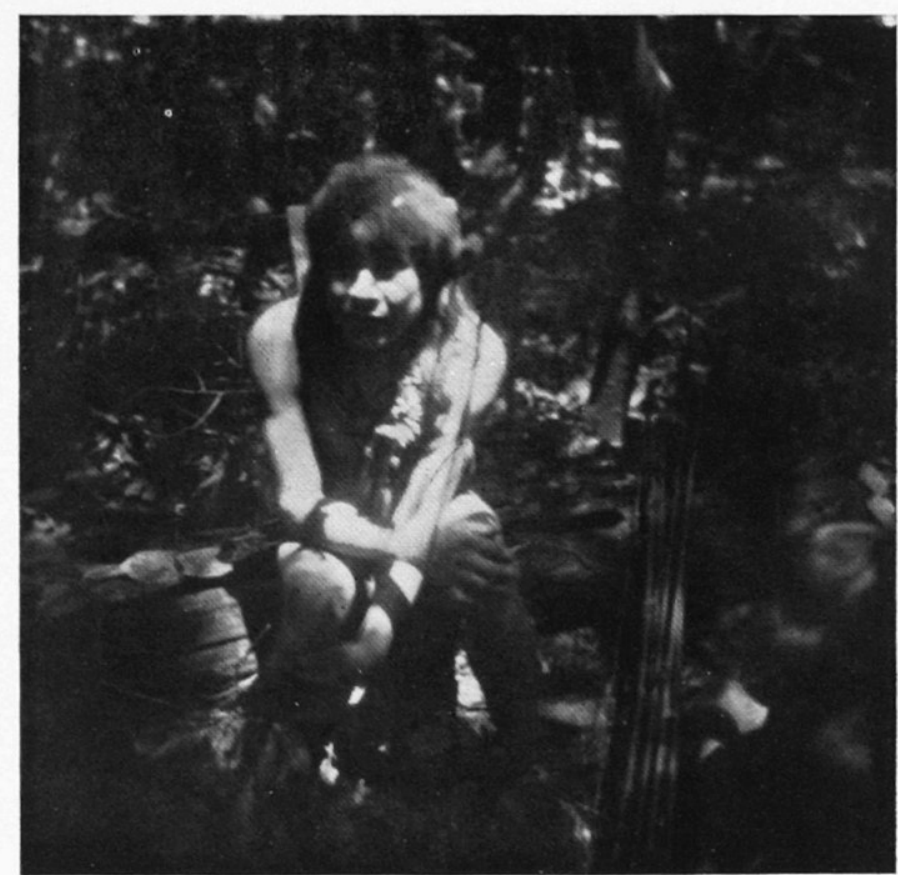

Foto 6. Wilde Wama-Indianen (man en jongen) in het woud, brongebied der Oelemari. Foto K. Meuldiik 5 Aug. 1937. 
eenkomsten zijn tusschen de karibische taalfamilie en een andere der (volgens Loukotka) ongeveer 100 zelfstandige taalfamilies van ZuidAmerika : de Kariri-groep in het achterland van Pernambuco (zie 4G).

De oudst bekende berichten van Europeanen, die met zekerheid betrekking hebber op de Oayana's, zijn van de $18 \mathrm{e}$ eeuw, en de mondelinge overleveringen der tegenwoordige Oayana's gaan niet veel verder terug. Mijn gastheer, de hoofdman en medicijnman Taponte en anderen, vertelden mij, dat vroeger de Oayana's en de Oepoeroei's uitsluitend ten Zuiden van het Toemoekhoemak-gebergte woonden, en wel, naar ik meende op te vangen, de Oepoeroei's in het stroomgebied van de Jari, de Oayana's in het stroomgebied van de Paroe. Op mijn vraag naar de Indianen met uitgerekte oorlellen, die La Haye in 1729 aan de Kuyari (een bronrivier der Jari) aantrof (Vi 119$125)^{1}$ ) antwoordde Taponte, dat het wellicht Oepoeroei's waren geweest; deze hadden ook huizen in boomen. Vermoedelijk in den loop der 18e eeuw hebben de Oayana's en Oepoeroei's zich ook ten Noorden van het gebergte gevestigd. In een strijd zijn de Oepoeroei's door de Oayana's overwonnen; deze hebben de Oepoeroei-vrouwen tot zich genomen en nu nog weet men aan te wijzen, wie van Oepoeroeiafstamming zijn; het is ook te hooren aan de uitspraak en aan het gebruik van enkele woorden die de volbloed-Oayana niet gebruikt.

Vóór de Oayana's zich aan de Litani vestigden, woonden aldaar Taira's (Kalienja's, Kariben, Galibi's) ${ }^{2}$ ) en vermoedelijk hoogerop stammen van de Trio-groep (C 79, 557 vlg. Okomayana's), in Suriname Akoeri's genoemd. ${ }^{3}$ ) Aan de Paloemeu-Tapanahoni hebben zich eerst omstreeks 1865 Oayana's, komende van de Paroe, gevestigd, op uitnoodiging van Djoeka-Boschnegers.

1) Hun naam „Namycouane” is klaarblijkelijk Tupi: nambi oor, kwara gat, evenals de naam der Nhambiquara's in Centraal Brazilië, die zelve geen Tupi's zijn. Op soortgelijke wiize noemden de Spanjaarden allerlei volken met uitgerekte oorlellen Orejone, of dgl. Zie voor stammen nog Frontières Atlas kaart 59, Lombard, Harcourt.

2) Ook vermeld Hartsinck I 3, C 257, 591 en J. A. van Heuvel 124 : ,... interview with Mahanerwa, the Charibee chief, at the head of the Essequibo river, ... The branch of the Charibees to which he belonged ... are the Teyrous (Tairas) of Cayenne". Waarschijnlijk het woord Terewuyu waarmede tegenwoordig Surinaamsche Kalienja's van onvermengd bloed zichzelve aanduiden (e Ahl, 2 Roth 675).

3) Tusschen Litani en Tapanahoni: Oayarikoelé of Tliometesem (zie foto 5) (wellicht sedert kort uitgestorven), Wama (ontdekt 1937-8, gebruiken nog steenen bijlen en hebben geen landbouw, zie foto 6); tusschen Tapanahoni-Paroe en Corantijn-Trombetas Trio, Pianakoto, Okomayana, Saloema (? de voorwerpen van hen afkomstig worden vervaardigd door Waiwai's en Taroema's); ver in het Westen, in Columbia Hianakoto. 
$\S 3$. De materieele cultuur der Oayana's zal, vóór er voorwerpen van Europeesch maaksel in gebruik kwamen, ongeveer aldus zijn geweest :

Levensonderhoud uit landbouw (bosch kappen, schoonbranden en beplanten, voornaamste gewas bittere kassave), uit visscherij en uit jacht; geen vee of lastdieren; huizen stroodak met houten geraamte; booten van boomschors; lange bogen en pijlen, geen pijlgift; platte oorlogsknotsen; aardewerk, vlechtwerk, koord van Bromelia-vezel en van katoen, geknoopte katoenen hangmatten; vuurboor; geen metaal; geen steenen bouwsels; neolithische steenen bijlen; overige werktuigen van hout, been, tanden enz.; als amulet of sieraad snoeren tanden, zaden, schelpen, misschien ook wel steenen kralen enz.; mooie vederentooi voor den ritus. - Men herkent in dit alles gemakkelijk het soort van cultuur der Indianen van tropisch Zuid-Amerika ten Oosten van den Andes.

Thans zijn bij de Oayana's de steenen bijlen verdwenen en men makt booten van een uitgeholden boomstam, gelijk de Boschnegers In het tijdvak tusschen mijn eerste bezoek (1903) en mijn laatste (1937) was het gebruik van dingen van Europeesch maaksel toegenomen. Overigens zij voor de materieele cultuur en de samenleving der Oayana's verwezen naar Crev, C, 1G, 2G, 9G.

$\S 4$. De geestelijke cultuur der Oayana's is, voor zoover ik het kon nagaan, van denzelfden aard als die der andere volken van Guyana en omgeving. Wat den Europeaan aanvankelijk leek het geloof of bijgeloof dezer menschen te zijn, is eigenlijk een soort natuurwetenschap. Ze verschilt van de onze, doordien de Indiaan een veel grooter aantal fundamenteele natuurkrachten erkent, terwijl bovendien die krachten van anderen aard zijn, n.1. van den aard van hartstochten, driften, instincten, aantrekking en afstooting, temperament, karakter.

Waarschijnlijk is de Indiaan daar sensitiever voor, dan de Europeesche verstandsmensch, en bovendien verschijnen den ingewijden Indiaan (medicijnman, sjamaan) de natuurkrachten aldus, op de wijze van droomen of visioenen, als hij in den toestand van trance of extase verkeert. Vermoedelijk geldt algemeen, wat 3 Nim 1004 zegt: „Die Quelle der ganzen Weisheit der Medizinmänner sind seine Träıme”. De Indiaan is dan als het ware in een bovenzinnelijke wereld, in een wereld van wezenachtige natuurkrachten of natuurwezens, natuurgeesten en meer omvattende geesten.

De geest, het werkend beginsel, is het oorspronkelijke; de zichtbare en tastbare wereld is een materialisatie van den geest, en wel elke 
soort van den geest der soort en de geheele wereld van den alomvattenden geest, de godheid, wiens wezen ,mensch" is.

Het vorenstaande is het volledigste bekerid van de Kalienja's, dank zij vooral de onderzoekingen van wijlen $\mathrm{A}$. Ph. Penard, en ziehier nog hoe een Kalienja zich uitdrukte: ,,als er geen geest was om alles te doen zijn wat het is, dan zou er ook niets bestaan" (pP 628).

De magie van deze Indianen is niet anders dan een hanteeren van die geesten of natuurmachten. Daar de Indiaan de macht, hoogheid en heiligheid van deze geesten erkent, hebben zijn wetenschap en magie ook het karakter van een godsdienst; in zooverre als lang niet elk hunner zelf de bovenzinnelijke waarnemingen heeft gehad, kan men het een ,"geloof" noemen. ${ }^{1}$ )

$\S 5$. De Oayana's zijn zwak in het tellen, en ze hebben geen rekenkunde. Men telt veelal op de vingers, beginnende bij den pink; na 5 zegt men kole-psik = veel-nogal; en, hoewel men kan voortgaan met de vingers van de andere hand en vervolgens met de teenen, bestaan daarvoor echter geen echte telwoorden. 1 pekenatpö verm. „begin”, 2 hakene ,in gezelschap”, 3 eheruwaw ,man” (?), 4 ehepetih-ne ,,met echtgenoote", 5 ehepetimüin ,,zonder echtgenoote”.

Het bezit dient tot gebruik en wordt na den dood van den eigenaar vernietigd, d.i. de geest ervan wordt bevrijd.

De taal bij de Karibische volken, drukt meer uit, hoe het gevoel reageert op gebeurtenissen of eigenschappen, dan dat ze de verschijnselen in een logische constructie vat. De persoonlijke voornaamwoorden, zelfs het woordje ,ik”, zijn eigenlijk aanwijzende voornaamwoorden. De zieletoestand die zich hierin toont, lijkt mij vergelijkbaar met het verzwakte ik-gevoel, dat wij in den droom beleven. Zie nader $7 \mathrm{G}$.

1) Vgl. nog C. G. Jung, De banden tusschen het ik en het onbewuste, Den Haag 1935 (vert.) pp. 96-7: „Het denkbeeld van een eigen psychische wereld is in het geheel geen nieuwe ontdekking, doch veeleer een der eerste en meest algemeene „Overwinningen" der menschheid; het is de overtuiging, dat een geestenwereld concreet bestaat. De geestenwereld is weliswaar nooit een ontdekking geweest, als bv. het vuur slaan, maar het was de ervaring of het bewust worden van het bestaan eener realiteit, die in niets bij de materieele wereld ten achter stond. Ik betwijfel, dat er primitieve volken zouden zijn, die de „magische macht" of "magische substantie" niet kennen (,magisch" is slechts een ander woord voor psychisch). Het schijnt ook, dat vrijwel allen aan het bestaan van geesten gelooven. „Geest” is een psychisch begrip. - De Indiaansche medicijnman zou hier vermoedelijk aan toevoegen: „En het innerlijk wezen der natuur is van denzelfden aard als dat psychische in mij, en daarop berust mijn kennis en macht". 
Bij alle Indianen van Guyana, en daarbuiten, kan men hooren van een vroegeren paradijstoestand, toen de menschen nog met de geesten verkeerden, en hoe door onachtzaamheid, ruzie of andere moreele fouten der menschen, de geesten zich aan de waarneming onttrokken. De medicijnman die zich in de extase begeeft, begeeft zich eigenlijk in dien vroegeren toestand. Evenwel zegt men, dat de medicijnmannen niet meer zoo sterk zijn als eenige generaties geleden, en meent ook wel, dat het Indianendom, of zelfs de geheele wereld, naar den ondergang gaat.

Oayana's die ik sprak, maakten onderscheid tusschen handelingen door medicijnkunst of magie (piai of püyai, zie § 10) en gewone handelingen. Dit wijst erop, dat ze al niet meer alles in een bovenzinnelijk verband beschouwen. En vrịwel steeds, als ik vroeg naar een geest, zeide men ,,vroeger zagen de medicijnmannen dien geest”, d.w.z. tegenwoordig niet meer.

\section{De godheid Kuyuli.}

$\S 6$. Het hoogste wezen waarvan de Oayana's vertellen, is Kuyuli (C 548 Kuyuri). Men zeide mij, dat hij iyumiyumiyumi-enma (i-yum vaderwezen, geestelijke macht, -enma zéér) is en dat hij een buitengewoon sterke piai (medicijnman, magiër) is.

Kuyuli is de schepper van alle geesten of bijzondere goden, schepper en voorvader van de Oayana's en alle andere Indianen, de Blanken en de Negers. Kuyuli is in den regenboog. De ziel van een gestorvene en de ziel van den medicijnman in de extase, stijgen ten hemel langs Kuyuli hanukatpö, K.'s ladder, wat ook de naam is van een op een ladder gelijkende liaan, die in Suriname en aan de Amazone „,schildpadtrap” heet (Bauhinia sp., foto Käyser afb. 4). Kuyuli schonk de elemi's (magische zangen of spreuken) en bij ziekte wordt o.m. Kuyuli aangeroepen.

Hoewel Kuyuli volgens die mededeelingen een machtig wezen is, mag men deze godheid toch niet zonder meer gelijkstellen met de Almacht volgens Europeesche opvattingen. Door vergelijken met de goden van naburige volken, kom ik tot de slotsom, dat waarschijnlijk oorspronkelijk met Kuyuli bedoeld werd een natuurgod, maangod, werkende in het vloeibare en in de voortplanting ${ }^{1}$ ) en dat hij de ,,jon-

1) Bij de Kalienja's is de regenboog de vederen hoofdtooi van een geest para-mu, zeegeest meP I 107, e Ahl 361), bij de Taulipang's is de watergeest (slangegeest) Keyeme in den regenboog; de met Kuyuli overeenkomende god- 
gere broeder" der Amerikaansche tweelingmythe was. ${ }^{1}$ )

Die mythe, in den vorm waaronder ze bij de Oayana's wordt verteld, laat ik hier volgen. Er zijn vele leemten in, doordien ik niet snel genoeg kon opschrijven, en ook, doordien mijn zegslieden het verhaa! niet goed kenden; het poëtisch karakter, dat meestal eigen is aan zulke verhalen, komt hier niet tot zijn recht. Het overeenkomstig verhaal bij C 549 is nog minder volledig; dat het, zooals $\mathrm{C}$ meende, een verhaal van christelijken oorsprong zoude zijn, lijkt mij geheel en al onwaarschijnlijk.

\section{De mythe van Kapu-pitani. $\left.{ }^{2}\right)$.}

$\S 7$. In den beginne was er een zwangere vrouw; men meent (doch mijn zegslieden gevoelden zich niet zeker), dat haar naam Kapao (hert) was, of dat ze een tutpö (kalebas met een gat, dienend tot waterkruik; als ze opgehangen is en de wind blaast in het gat, dan

heid der Tamanaco's enz., Amalivaka, heeft te doen met draaikolken en met watergetijden (2KG III 176, 180, Gilij III 5, 1Roth 136). Bij de Tamanaco's was het een godheid Japituari (welke de kassavewortels deed zwellen), die langs een trapliaan ten hemel steeg (Gilij III 11), bij de Taulipang's en Jibaro's de maan, en volgens een Jibaro-mythe is die liaan ontstaan uit het achter elkaar afschieten van pijlen die een keten vormden (2KG II 54, 277. III 209, 211, 2Kar 519-22, 526); het mythen-motief „pijlenketen als hemelladder” komt ook bij andere volken van Zuid Amerika en in Noord Amerika voor (3KG 334-5).

1) De tweelingmythen (althans die van Guyana en omgeving) mogen wellicht worden opgevat, als het verhaal van de inwijding, zooals de halfgod-voorvader die heeft doorgemaakt tot voorbeeld voor de nazaten. Men kan ze ook opvatten als het verhaal van de geboorte der menschelijke ziel uit de natuur, haar lotgevallen in het rijk der demonen en haar uiteindelijk ten hemel stijgen. De tweelingbroeders (soms zijn er nog meer broeders, of ook een zuster) zouden dan verschillende eigenschappen der ziel vertegenwoordigen. De ,,jongere broeder” (in sommige verhalen eigenlijk een bastaard, de zoon van "Buidelrat”) is de zwakkere en zit vol streken; hij is de voorvader van den eigen stam (of van de menschen in het algemeen) en is ook de cultuurbrenger; wellicht wordt hier bedoeld het verstandswezen in den mensch. De „oudere broeder" (in sommige verhalen de zoon van den zonnegeest) helpt zijn broertje telkens uit de moeilijkheden en wellicht wordt hier bedoeld het natuur- en instinctwezen in den mensch. Mythische figuren die vermoedelijk samenhangen met dezen ouderen broeder, zijn , ,de eerste medicijnman”, „de woudgeest” en de man „,zonderdijbeen" die aan het uitspansel het sterrebeeld Orion is. Verschillende bijzonderheden in deze, of hiermede samenhangende mythen, lijken zinspelingen op de voortplanting, doch ook hebben ze waarschijnlijk betrekking op hemelverschijnselen, in het bijzonder op de maan. Dat alles kan tegelijk bedoeld zijn, daar naar Indiaansche opvatting in het heelal de wet der gelijkenissen of harmoniën heerscht (meP II 23). Zie ook 5G $501 \mathrm{vlg}$.

2) Of kapu-mumkö, d.i. hemelszoon (Kuyuli), of waarschijnlijker hemelskinderen (de menschen). 
maakt het geluid) was. De vader van haar kind was, naar men meent: Taun (de wind, of lucht; Taun noemt men ook een wezen, huizende in een grooten boom); of šiši, de zon, of $k a p u$, de hemel, was de vader.

Die vrouw kwam aan een dorp van tijgers ${ }^{1}$ ), waar een oude vrouw, Pële (pad), was. De tijgers waren op de jacht; toen ze thuis kwamen, roken ze, dat er iemand gekomen was; ze zochten, vonden de vrouw en doodden haar (een der verhalers zeide: ze aten haar hoofd op). Pële redde het embryo, dat was gelijk een kippenei; de tijgers wilden ook dat hebben, doch zij zeide, dat het slechts een ei was.

De oude vrouw had het kind in een pot gestopt en ging met het kind naar een andere plaats. Het kind, Kuyuli, sprak eerst als een kleine papegaai, daarna als een groot soort papegaai (ander verhaal: als een duif) en het groeide op onder de hoede van zijn pleegmoeder Pële.

Kuyuli maakte door tooverkracht een groot huis; de tijgers kwamen en dansten in dat huis; toen viel er zware regen, het huis stortte in, en alle tijgers stierven. Zoo doodde Kuyuli de tijgers die zijn moeder hadden gedood. Alleen de tijger Këlëpuke was niet in het huis gegaan.

[Wat nu volgt, werd door verschillende vertellers niet in dezelfde volgorde medegedeeld]. Kuyuli jaagde en vischte voor zijn pleegmoeder en deze at den buit op. Doch Kuyuli had geen vuur om het toe te bereiden en hij leed van de koude. Want er was nog geen vuur, alleen zon. Doch de kalao (vogel Ibycter) verklapte, dat Pële het vuur in haar anus had. Kuyuli wilde vuur maken onder de kassave-bakplaat en vroeg vuur aan Pële. Deze wierp vuur weg, K. pakte het, een stukje brandend hout, verborg het in zijn mond, waar het hem brandde, onder zijn lendendoek, waar het hem brandde; er kwam (hij deed) water bij, doch toen de avond viel, was het vuur gedoofd en toen ging hij naar zijn dorp en maakte met pijlriet (de vuurboor?) vuur.

Ook had Pële aan haar ooren kutuli (kleverige koek van kassavestijfsel; oorvuil noemen de Oayana's ook oor-kutuli) ${ }^{2}$ ).

1) Kaikui, de algemeene naam van alle katachtige roofdieren, in Suriname „tijger" genoemd; ook honden worden zoo genoemd, en mythische wezens; beduidt vermoedelijk ,verscheurend dier”, gelijk Tupi yawara (waarvan het woord ,jaguar").

2) De pad of boomkikker als pleegmoeder der tweelingen, melkvocht en vuur, in verscheidene mythen (1Roth 123-125, 130-135, 2KG II 76, 1Far 146, Metr 
Kuyuli had een kameraad, die Mope heette.

Kuyuli maakte van vlechtriet Oayana's, vervolgens Negers, Franschen, Hollanders, Aparai's, Taira's; zij allen hebben Kuyuli tot vader. Hij nam een indiaansche vrouw (ander verhaal: hij kweekte een wijfjesbrulaap op en deze werd zijn vrouw). Hij kreeg een zoon, Pëlikaman (Pële's kleinzoon?); ander verhaal: hij verwekte twee zoontjes; of: een zoon Mopo (C 552 Mopere) en een dochter Mokaya (C 552 Uelepo $^{1}$ ).

Kuyuli was overdekt met $\ddot{e} l i k$ (groote huidwonden) en zijn vrouw wilde niets van hem weten en gaf geen gehoor aan zijn verzoek om hem kassavebrood te brengen ${ }^{2}$ ). Hij verwierp haar en ging heen. Hij en Mope dansten en bij het aanbreken van den dag onderging hij de wespenproef ( $\S 41)$, die, evenals het gebruik van den dansvloer, door hem is ingesteld; hij had den olok (hoofdtooi) op en blies op de reuzengordeldierfluit ( $(42)$.

[Wellicht behoort het volgende brokstuk op deze plaats in het verhaal:] Kuyuli en Mope waschten zich en hun huid werd mooi. Zij aten kupe (vrucht van Genipa americana) en op hun huid verschenen de zwarte teekeningen, het sokane-patroon, en andere ( $\S 11)$. Toen later Kuyuli heenging heeft hij dit, als zijn tooverkracht (piai, t-epiem), den menschen gelaten, als zijn ,pampila” (papier, waarmede vermoedelijk bedoeld ,schriftteekens”. Vgl. nog Metr. 27).

48, $1 \mathrm{Nim} 397$, Preuss 57). Dat dit beeld gekozen is, laat zich verklaren uit de volgende eigenschappen: 1 . bijzondere moederzorg; 2 . huppen naar vuur en men kan ze in een stuk gloeiende kool laten bijten; de huid ziet er als verbrand uit; 3. afscheiden melkvocht; het vocht van padden wordt soms gebezigd om bij levende vogels de kleur der vederen te laten veranderen, en als pijlgift, Wassen 617,622 . De verwantschap tusschen pad of kikker en tijgers, laat zich verklaren uit beider bekwaamheid in de jacht. De Oayana's noemen Hyla venulosa kunawa, en den reuzentijger (geest) die de menschen met een strop vangt, kunazvalu-ime; zie ook Tat $138,1 \mathrm{BR} 62,5 \operatorname{Str} 430, \operatorname{Str} 678$, en over de bereiding van een jachttoovermiddel Wassen 621, 1Roth 278-9, e Ahl 240. De tweelingmythe die Penard van een Kalienja vernam (De Periskoop 12 Sept. 1925) vermeldt van Pololu-noto de paddengrootmoeder: ,Zij was een liefje van Weyu (de zon) geweest, maar deze had haar verlaten. Hij was de vurigheid in persoon en beminde het warme licht, zij was de koelheid zelf en verkoos de kille duisternis". In de Guarani-mythe (1Nim 397) maakt Oudere broeder de pad, die het door gieren gebrachte vuur opslokt.

1) Vgl. Kalienja mope wilde pruim Spondeas lutea, mokaya palm met eetbare vruchten en smakelijk sap Acrocomia sclerocarpa.

2) Iets dergelijks in mythen van de Taino's (Roman Pane Cap. VI, in Raccolta Colombiana), Uitoto's (Preuss 90-91), Tupi's (Metr 12-14, 232-4) en Inka's (Kr 251 vlg., 383). 
Kuyuli had de Oayana's geschapen en zij waren onsterfelijk, doch nadat zij zich aan geslachtsverkeer zijn gaan overgeven, zijn zij sterfelijk geworden. (Ander verhaal: de lichamen der Oayana's waren ondeugdelijk. Ander verhaal: de Oayana's pleegden overspel).

$\mathrm{Nu}$ steeg van onder den dansvloer het water op en overstroomde het land en alle Oayana's kwamen om het leven (ander verhaal: Kuyuli en Mope staken hun voet in een vijzel en uit dien vijzel kwam het water opzetten.

Kuyuli nam plaats op de kunana (wespenbord, § 41) of op een ander vlechtwerk, of werd een kalebasje, dreef op het water, en ging naar zijn groote dorp in den hemel, waar alle vruchten vanzelf groeien. De kinderen klommen op een moritiepalm (ander verhaal: de kinderen redden zich op een pëmuit (vrouwenwerkbakje van vlechtwerk) of op een pamkali (kassavezeef) waarop ze een ako-yep (vijzelstamper) plaatsten en dat werd als een moritiepalm; C 549 ze klommen op een hoogen berg, aldaar op een huis en daarna op twee daarop gestapelde vijzels en toen zagen ze een moritiepalm voor zich). De kinderen klommen op den moritiepalm en wierpen kleine kalebasjes naar beneden ${ }^{1}$ ).

(Ander verhaal: Kuyuli en Mope verbrandden den reusachtigen Ceybaboom, thans nog aan het uitspansel te zien, de Melkweg, Kumaka-hazvalu-tpö = Ceyba-branden-voormalig. Het vuur viel op aarde en daarna kwam er regen. Op den roodgekleurden aardbodem maakte Kuyuli van pottenklei een hoog cylindrisch huis. De sikale (soort koekoek) waarschuwde om kassavebrood enz. in het huis te brengen. De regen kwam en het water wies; toen het weder daalde, overtuigde men zich van den stand van het waterpeil door gaatjes in den wand te boren. Toen ze het huis openden, waren er geen boomen meer op aarde).

Toen het water gedaald was, aten ze komboepalm-wormen en Pëlikaman werd ziek en stierf. Kuyuli hoorde Pëlikaman zingen en zag een groot huis en daarin Pëlikaman dansende. De kinderen hadden honger, en Kuyuli, in de gedaante van een pakalaimö (groote reiger, vgl. § 9, ,alakataši gelijkend”, vgl. C 552 de vader heet Atakasi) bracht hun voedsel.

1) In verscheidene zondvloedverhalen redden enkele menschen zich op een hoogen berg. Bij de Trio's is dat de rots Kantani 2G 12 (later door generaal Rondon „Pico Ricardo Franco" genoemd). Een Oayana vertelde mij van een rotsberg Alamatali-tepu in de savane, naar ik meen als plaats van oorsprong der Indianen, doch het verhaal was niet duidelijk. 
Vermoedelijk volgt nu, wat C 549 mededeelt en wat ik hier verkort weergeef :

De jonge man ging naar zijn vader in den hemel. In diens dorp was er overvloed van voedsel, doch geen vuur; men droogde er de kassave in de zon.

De vader gelastte hem, een kassavepers, zeef enz. te maken en daarna kassave te halen. Onderweg werd de zon steeds heeter en op een volgenden tocht vond hij naast een kostgrond (akker) een beekje, dat ,zon” was, komende van een rots die „vuur” was. Later vonden broer en zuster een huis welks palen ,kassavestammen” waren. De jonge man vergat telkens zijn kassavepers, zeef enz. De vader gelastte hem, ze te zoeken, doch de jongen vond, dat de kassavepers een boa-slang was, de zeef een zwerm moglazvale-wespen, het brandhout een pak slangen. ${ }^{1}$ ) Toen hij bij zijn vader terug was, kwamen de voorwerpen vanzelf aanloopen, doch thans in hun gewone gedaante. De vader gelastte nu zijn kinderen, naar de aarde af te dalen en een mand met kassave mee te nemen, benevens twee stukken vlechtriet, kassaveplanten en alle andere planten die men kweekt. Het stuk hout ontbrandde vanzelf en ze behoefden voortaan dat vuur slechts te onderhouden. Uit de twee schalen, die behoorden tot eenzelfde kalebas, kwam een menigte Indianen en Indiaanschen.

Men leefde gelukkig en toen hechtten de jongen en het meisje vuurroode ara-vederen aan hun schouders en ze vlogen naar hun vader in den hemel. - Tot zoover $\mathrm{C}$.

$\mathrm{Na}$ den grooten watervloed heeft Kuyuli opnieuw Oayana's geschapen: de voorouders der tegenwoordige Oayana's. Kuyuli schiep ook de Negers en de Blanken en de rivieren en alle werktuigen. Hij had bijlen en alle koopwaar; de Oayana's waren bang, de Blanken echter niet, en zoo kregen de Blanken de koopwaar. (Ander verhaal: van Kuyuli, in het Oosten, stammen de Franschen af, van Mope in het Westen, de Hollanders; daarom hebben de Franschen slechte en de Hollanders goede koopwaar).

Kuyuli is naar de Paroe gegaan en heeft daar een huis van planken gemaakt en is ten hemel gestegen (ander verhaal : Kuyuli is de Marowijne afgezakt nog verder dan waar de Blanken wonen, naar een zeer groot water). Men heeft Kuyuli niet meer gezien (C 551 hij heeft nog een keer de nieuwe menschen bezocht).

1) Waarschijnlijk gaan de jongelieden hier door het gebied der natuurgeesten, voor wie de aardsche dieren, voorwerpen enz., iets anders zijn, dan ze voor de menschen zijn; zie o.m. 2KG II 16, III 223, pP 649.

1)!. 106 . 
Ahl. vernam: Kapupono maakte den mensch uit aarde, doch toen de mensch baden ging, smolt hij weg. Toen makte hij den mensch uit vlechtriet; de mensch ging op jacht, regende nat; kroop bij het vuur en verbrandde. Daarna maakte Kapupono den mensch uit vleesch en bloed en toen was het goed. ${ }^{\mathbf{1}}$ )

\section{De mensch.}

$\S 8$. Een opsomming van verschillende zielen of deelen der ziel, heeft men mij niet gegeven, doch drie woorden: amole, akuali en yolok zouden als ,ziel” kunnen worden vertaald.

Amole noemt men de schaduw van een mensch; eu (oog)-amole is het menschenfiguurtje dat men in iemands oogpupil kan zien. Ook beduidt amole, levensbeginsel; amole-p-hak (amole-vervuld-met zijnde) zegt men van iemand die snel of ijverig werkt, van vlug praten en van hartkloppingen. Als men iemands huid aanvat, of hem slaat, zoodat hij erg schrikt en tiẹphe (koortskoude of koorts) krijgt, dan is dat, doordien de amole was uitgetreden. Toen ik (in 1907) een op den grond liggenden haarlok van Soekoema, die medicijnman was, wilde meenemen, zeide hij $\mathrm{cu}$ yomhet-psik telei, iy-amole t-utat-se (mijn haar een weinig meenemen, mijn amole verdwalen). $\mathrm{Na}$ een sterfgeval knippen echtgenoot(e) en naaste verwanten van de(n) doode hun hoofdhaar af (zie foto's 9, 11), dat in de rivier wordt geworpen of verbrand. Men zeide mij, dat als dit haar verbrand wordt, de betrokkenen blijven leven, niet sterven. De amole is in het lichaam; tijdens den slaap verlaat zij het lichaam, om te droomen en keert bij het ontwaken weder terug door den mond, of op de wijze als men een hemd over het hoofd trekt. De Kalienja's gebruiken het woord amole met de beteekenis van ,de vermogens van den medicijnman".

Akuali noemt men de schaduw van een mensch, het beeld op het scherm in de cinema en ook de echo. Ook beduidt het iets dat na den dood blijft voortbestaan en naar Kuyuli gaat. In het Kalienja is $y$ akuwa de beschermgeest; het woord staat in karibische talen in verband met woorden die sieraad, kristal, het goede of schoone, aanduiden. Het leek mij, dat men de woorden amole en akuali wel eens door elkaar gebruikte. Als men spreekt over de ziel buiten het lichaam

1) Den naam Kapu-po-no (hemel-in-persoon) heb ik nooit hooren noemen en ben geneigd erin te zien een tegemoetkoming van den Oayana aan den Blanke, die hem vroeg naar God in de hemelen. 
(in den slaap, na den dood, in de extase) dan zegt men amolimpö en akualimpö (-m-pö voormalig); bij een doode sprak men van diens akuali-yoloko-n, de yolok van de akuali.

Yolok noemt men de ziel van een doode, doch ik heb dat voornamelijk gehoord, als men sprak van een doodenziel die rondspookte; en dan was het altijd de ziel van een overleden medicijnman die over iets vertoornd was, of kwaad van aard. Eveneens noemt men yolok, de geesten die de booze medicijnman uitzendt naar iemand die hij kwaad wil doen. Doch dat zijn eigenlijk dezelfde soort geesten, waarvan de goede medicijnman zich bedient om te genezen. Voorts noemt men yolok de geesten die, voor het gewone oog onzichtbaar, in menigte in de natuur rondom ons zijn. Vermoedelijk gaat het dus slechts om één soort geesten, die zoowel de geesten der natuur, als de geesten van het menschelijk lichaam zijn ${ }^{1}$ ), en in het laatste geval, zoowel voor booze als voor goede doeleinden gebruikt kunnen worden.

Lettende op hetgeen bij andere volken is aangetroffen, ware het mogelijk, dat de Oayana met akuali en amole bedoelt het hemelsche element der menschelijke ziel, en met yolok het aardsche residu der ziel $^{2}$ ).

Op mijn vraag omtrent reïncarnatie, bleek niet, dat men daar iets van wist. Op mijn vraag, waar vrees en moed zetelen, meende men, dat dit is in hoofd, hart en lever, of in oogen, hart en lever. Het woord yamephak = vriendelijk of verstandig van aangezicht, staat in verband met emephaku hersenen en met Kalienja eme manieren, zede, emepa onderwijzen, embata aangezicht.

\section{Hemel en onderwereld.}

$\S 9$. De lo (bodem, aarde) waarop wij staan, is eigenlijk niet $l o$,

1) Er zijn vele berichten dat een ziel na den dood een natuurgeest werd (1Roth 170,153, 163, 178, Gilij III 15, 2Kar 112, 3Kar 373, 1 Kar); en dat geldt niet alleen van slechte zielen, doch ook van zielen van goede medicijnmannen, die door een levenden medicijnman te hulp geroepen kunnen worden (1Roth 178, 349, perP 76, 2KG III 196, Gus I 740) en ten deze dus vrijwel gelijk staan met zijn helpende natuurgeesten.

2) Vgl. Kalienja yolok duistere geest, ,duivel"; het hoofd dezer geesten is de oudste der goddelijke tweelingbroeders; $y$-akuwa helpende geest, ,engel"; het hoofd van deze geesten is de jongste der goddelijke tweelingen. pP 643 „De vertoornde goede geest doet soms kwaad. De goedgezinde kwade geest handelde ook wel braaf”. 652 ,Sommige $y$-akuwva-kon willen yolok-an-gon worden, waarom zij naar Emanbo (ochtendlooze, het oord der duisternis) verhuizen. Vele yolok-an-gon vestigen zich te Komamba (avond-looze, het oord van het licht) als $y$-akuwa-kon". - Uit deze, en andere, mededeelingen laat zich afleiden, dat naar Indiaansche opvatting, de mensch zelf het kruispunt is van goed en kwaad. 
doch ehemanali (een drijvende massa van een waterplant); de echte $l o$ is in den hemel. Onder den bodem waarop wij staan is tuna (water $)^{1}$ ); daar wonen tuna kaikui, oergeesten (§ 11) die, als zij aan de oppervlakte zouden komen, de menschen zouden verslinden; voorts is daar het dorp der Oayana's die door den grooten watervloed verzwolgen werden.

In den hemel boven ons zijn Kulum (de zeer groote gier, Gypapus papa), Wantingkë (kleinere gier) en Awila (kleinere gier) (op iets dergelijks doelt C 209, 533, 549; ook 1G 26, 2G 12, Sp 222 en zie $\S 50)$; deze zijn „,Oayana”; als ze naar beneden komen om te eten, hangen ze hun vederkleed om. Tot dien hemel behooren ook de sterren $(\S 12)$.

Boven dezen hemel is een tweede hemel; deze is Tukušima-pata, de plaats der Tukušima's (zeer groote ooievaar, Mycteria americana). Dat is ook de hemel van Kuyuli, Mope en Pëlikaman. 5 Augustus 1937 streken op een hoogen boom bij het dorp van Taponte eenige dezer vogels neer; men zeide mij, dat het dragers van booze yolok's waren (die ze ,op de manier van je hemd” dragen), gezonden door een slechten medicijnman om dood te brengen onder de Oayana's.

Mij werd gevraagd, of ginds, ver weg, aan de Amazone-rivier, de hemel dichter bij de aarde is dan hier. Toen in 1903 eenige Oayana's ons op den $500 \mathrm{~m}$ hoogen rots Knopoiamoi bezochten, meenden zij, dat daar de hemel dichterbij was ${ }^{2}$ ).

1) Het woord tuna (water) gebruiken de Kalienja's om de hemelsche wateren (zooiets als de wereldether) aan te duiden, het woord pao (eiland) om een geesten-,,plaats" in die wateren aan te duiden. Het is mogelijk, dat dit de oorspronkelijke beteekenis is, en dat men slechts bij wijze van vergelijking, aardsch water tuna en een aardsch eiland, en ook „land” (woonplaats van een volk) pao noemt.

2) Volgens de Kalienja's bestaat het heelal uit een reeks van verdiepingen, zoowel van boven als van onder (meP I 107, pP 646 vlg.); ook bị andere volken is een dergelijke opvatting aangetroffen.

De gieren kunnen zeer hoog vliegen, zoodat men ze als een stipje aan den hemel ziet verdwijnen. In verscheidene mythen wordt de held door een gier (-geest) naar den hemel gevoerd; dat is zoo goed als zeker een wedergave van wat de Indiaan in de extase beleeft. - Als gieren op een stuk aas neerstrijken, dan komen, naar men zegt, eerst de gieren van een kleine soort, dan die van een grootere soort en ten slotte de allergrootste gieren, in Suriname tiengi fouroe granman, stinkvogel-opperhoofd, geheeten (vgl. 2KG II 9, III 187). Ook de Mycteria Americana kan zeer hoog vliegen. Tukuš-ima laat zich vertalen als ,kolibri-geest”. (Vgl. Kalienja Tukayana, naam van den geest die den medicijnman in de extase naar den hemelen voert en hem daar rondleidt, opperste der tabaksgeesten en boodschapper tusschen medicijnman en den lichtgod. Volgens eenige mythen (1Roth 335,338 en hierbij 1 BR163 = 3KG 153) 
De oorsprongsgeesten. A f beeldingen.

$\S 10$. De Oayana's kennen een menigte geesten (,geest" op te vatten als in $\S 4$ besproken). Een medicijnman die sterk genoeg is, ziet ze, als hij in de extase verkeert.

C 208-9 onderscheidt de yolok's (reeds vermeld $\S 8$ ), die de uitvoerders van het lot zijn en als zoodanig de Indianen kwellen, en boven deze de „Esprit-Piayes”, geest-medicijnmannen, die den aardschen medicijnman helpen. Maar er blijkt, dat dit toch eigenlijk dezelfde geesten zijn, n.l. de oergeesten der verschillende soorten van dieren (of ook planten of andere objecten-) en vermoedelijk is het verschil slechts, of ze in het duister blijven en den mensch overheerschen, of dat ze den mensch dienen, wat het geval is bij dengene die ze overwonnen heeft, d.i. den medicijnman. Men zeide mij ,de yolok's zijn kwaad, doch in de medicijnhut zijn ze goed”.

Wat dat woord piai of pïyai betreft, noteerde ik de volgende beteekenissen: püyai medicijnman; püyaši (als een persoonsprefix voorafgaat-iyaši) amulet; in de magische spreuken van $\S 23$ vlg. komen de woorden püyaše en ase, asi- $n$ voor, waarschijnlijk met de beteekenis van ,helpende geest” of ,magische macht van zoo'n geest”. Vrijwel alle karibische volken duiden den medicijnman aan met het woord piai, puyai, piase of piasan; wellicht is het verwant aan Pia, naam van den oer-medicijnman (zie $\$ 43$ noot), en vgl. Taulipang

heeft de kolibrie het tabakszaad uit het land der tabaksgeesten gehaald en op die lange vlucht heeft de Mycteria-ooievaar hem gedragen. Een Arawak, die mij een dergelijke mythe vertelde, zeide dat de kolibrie eigenlijk de medicijnman zelf is. (Vgl. 1Roth 371 en vgl. Arawak seme zoet, seme-he goede geest, semetši medicijnman, bimiti kolibrie, Eiland-Karibisch (verwant aan Ar.) bime zoet, šeme geest, god).

Hierdoor valt een licht op de overlevering van het asphaltmeer op Trinidad, vermeld Kingsley (At last) : For - so the Indian story ran - once on a time a tribe of Chaymas built their palm-leaf ajoupas upon the very spot where the lake now lies, and lived a merry life. The sea swarmed with shell-fish and turtle, and the land with pine-apples; the springs were haunted by countless flocks of flamingoes and horned screamers, pajuis and blue ramiers; and, above all, by humming-birds. But the foolish Chaymas were blind to the mystery and the beauty of the humming-birds, and would not understand how they were no other than the souls of dead Indians, translated into living jewels; and so they killed them in wantonness, and angered „The Good Spirit”. But one morning, when the Guaraons came by, the Chayma village had sunk deep into the earth, and in its place had risen this lake of pitch. So runs the tale, told some forty years since to M. Joseph, author of a clever little history of Trinidad, by an old half-caste Indian, Señor Trinidada by name who was said to be nigh one hundred years of age. 
2KG III 239, 265, 185 enz. pia en iasi met de beteekenis van magische kracht of geest. Het ware mogelijk, dat deze woorden ongeveer dezelfde strekking hebben als manitu, orenda of wakan in Noord Amerika, mana in Polynesië, obia der Negers in Suriname.

$\S 11$. Hier volgt een opsomming van die geesten welker namen ik vernam. De uitgang -imö in die namen, wordt ook gebezigd om een bijzonder groot exemplaar van een soort aan te duiden, doch hier beteekent het waarschijnlijk ,geest” ${ }^{1}$ ). De uitgang -tamu = grootvader, oude; de uitgang $-y u m=$ vader, oude; de uitgang - umuit misschien $=$ wortel ; de uitgang - pai misschien $=$ medicijnman. Dikwijls werd erbij gezegd, dat de genoemde geest kaikui (tijger, verslindend wezen) was, of tuna kaikui (verm. verslindend wezen der hemelsche wateren, zie ook $\S 9)^{2}$ ).

Geesten: Alalawai (alalawa blauw en gele ara); Alawataimö is een tuna-kaikui (alazvata brulaap); Alimi-iyum die duisternis en wind veroorzaakt (alimi zwarte harige aap, Ateles); Alimikulcimö die Oayana-kinderen lokt en ze tot apen maakt; Atulaimö, watergeest (atula ijsvogel); Aualipaimë; Awokoimö (awoko hoen Crax); Ëtpaimö (ëtpa klein vischje); Hamutuimö (hamut zand); Hulukhulukuimö; Kapaoimö (kapao hert) ; Kapu maakt geluid ,als het stampen in een vijzel" ( $k a p u$ hemel, donder); Kapupairan die als vuur, als een geweer is, wellicht de bliksem, die een godheid is $\left.(\text { paira-n }=\text { zijn boog? })^{3}\right)$; Kalazuimü ; Kunuloimö een tuna-kaikui, misschien dezelfde als Kunulopai, een groote kaikui met scharlakenrood bovengedeelte, die iyum (geestkrachtig, oud) is, en een machtige

1) In het extatisch visioen verschijnen den Indiaan de geesten van dieren, planten of voorwerpen als een zeer groot individu van de betrokken soort, en ook wel in menschengedaante (perP, $\mathrm{pP}$ 628). Als men in de natuur een zeer groot exemplaar ziet, dan wordt dit soms aangezien voor een materialisatie van den soortgeest (1Roth 173, 192). Soms geldt een diersoort als soortgeest van een andere diersoort of ander natuurobject. De betrekking tusschen beide kan zijn: gelijkenis in uiterlijk of in eigenschappen; samenwonen; de eene soort voedt zich met de andere. De karibische uitgang -ima, -imo, -imö, ook wel -imu, is vermoedeijk verwant aan yumu (Kalienja ook yumang), vader of vadergeest of was oorspronkelijk hetzelfde woord.

2) Vgl. 2KG III 188 en Arawak -kuyuha = geest, en ook de schuwheid of wildheid van een dier.

3) Ook in enkele arawak-maipure talen worden uitspansel en donder met hetzelfde woord aangeduid. De Tamanaco's zeiden, dat de donder het losbranden van het geweer van den god Kinemeru is, die dezelfde is als Kanepo, wiens urine de regen is (Gilij II 230-1, III 27-8); karibische talen kono-po regen, kono-meru donder, bliksem (meru sterk geluid, kracht). 
piai (kunolo roode ara) ${ }^{1}$ ); Kunuwalimö zeer groote zwarte kaikui, vangt de menschen door ze een strik om te werpen (kunawa melkkikvorsch); Matazvanaimö watergeest, als een zeer groote otter (matawale een vischsoort); Maulumani als een kind; Mautapai; Payagwa-tamu zoo groot als een mensch en met een olok (vederkroon) (payagua vogel Cassicus persicus) ; Pakaraimö (reigersoort); Pakiraimö, volgens sommigen een tuna kaiku, is een iot-tamu (wildgrootvader (pakira klein soort zwijn); Peneimö, watergeest (pëne pirai, roofvisch); Poineke-tamu, Poinekeimö (poinëkë groot soort zwijn) ; Putu in het woud; Sipipinmö is een ka-yum (visschen-vader); Tiemi; Y uhmunuli, Ihmunuli, een tuna-kaikui, zoo groot als een tapir, en, wellicht dezelfde: Ulu- ̈̈imuit een $\frac{1}{2}$ à 1 meter groote kassaveknol (C 209 piaye-manioc) (ulu-imun kassave-knol): Wališimaimö (ališime miereneter); Yalawa, zeer groote otter, is een tuna-kaikui.

Op mijn vraag, of men ook een vrouwelijken watergeest kende, was het antwoord: ja, de tuna wahlumali-n Olišiši; deze is ipokeraohamna (uitermate kwaad) en een sterke piai. Een andere watergeest is als een watervarken (Hydrochoerus) en is behaard met witte haren als Bromelia-vezels. Zie voort nog de in de tooverspreuken, § 23 vlg., aangeroepen geesten.

Zeer veel wordt afgebeeld Kueimë, een tuna-kaikui en ka-yum; kucimë heet ook de rivier-torenslak. En Molokot, eveneens een kayum; molokot is ook een visch, vermoedelijk Myletes sp. Men vertelde: de Molokot is in de rivier, prachtig mooi, als een ašitau (Myletes sp.); wie hem schiet zal in alle water dat hij drinken wil, den Molokot aantreffen en sterft; de Molokot doet hem uitteren, of maakt, dat hij niet kan drinken en eten ${ }^{2}$ ). Een andere dikwijls afgebeelde watergeest is Sipalat $=$ krab. Nog een andere Watau $=$ een visch, Myletes sp.

Voorts de Kuluwayak of Akunwayak, die iyum is en in het woud is, en afgebeeld wordt als dier met twee koppen, die kuifveren hebben als een aigrette en twee (vier?) pooten ${ }^{3}$ ). En de Meliwala, vermoedelijk dezelfde als Melimë (meli = eekhoorn) in het woud, die van den eenen op den anderen boom springt. Voorts de Palité, en

1) Vgl. Kal. konolo-yana de scheppende grootvader der papegaaien en parkieten; Taul. wato-ima, een ara die dienaar van den watergeest is. (pPen 639, 2KG III 180-1).

2) Iets dergelijks in Peru, Te 290; en vgl. Kalienja de geest mulokoto een watergeest, de grootvader der haaien; Karibische talen moro visch, -koto suffix van persoons- en stamnamen, misschien ",roeper".

3) Tweekoppige dieren (geesten) vermelden Metr 36, 2 KG II 10. 
Sikalewot als een wesp (sikale soort koekoek). Van deze geesten werd gezegd, dat ze kaikui zijn, of ëlukë (rups, worm, ,draak”?) en menschen eten. Deze, en misschien nog andere geesten, zijn geen yolok, maar in wat voor rangorde ze dan wel thuisbehooren, heb ik niet vernomen. Wellicht behooren nog tot dezelfde soort: Mekuom (meku= capucijneraap; vgl. pPen $641 \mathrm{Kal}$. de boschgeest Mekuimio die zich voordoet als een abnormaal groote capucijneraap), Napiala (napi, zoete patat).

Vogels die eigenlijk geesten zijn, zijn, behalve de reeds genoemde gieren en ooievaar, ugrai (geitenmelker; vgl. 1Roth 161, 175), sikale (soort koekoek), onole (een reigersoort), wayowayo (boschwachter, Lathria), mamak tiriri (moeder van het gedruis of het beven) en een kleine vogel die 's nachts wïi wüi roept, welke in ouden tijd een machtige yolok was, die Indianen verslond. ${ }^{\mathbf{1}}$ ). Het insect Mantis religiosa is yolok-apsik (een weinig demon); als dit zich op iemand neerzet, dan ,barst zijn hoofd”, of hij wordt ziek en sterft. Het vleesch van den drievingerigen luiaard wilde het gezelschap-Apetina niet eten.

Misschien behooren ook tot de geestenwereld de navolgende volken die Taponte mij noemde: 1 . Olisiana, een stam van uitsluitend vrouwen (oli, olisi vrouw), die geheel op de wijze van mannen in hun levensonderhoud voorzien; 2. Sieuyana, die deze vrouwen bezoeken en ,gelijk de honden, bij klaarlichten dag" met hen paren, dan baden, eten en heengaan (sicu honigbeertje); mannelijke kinderen worden gecastreerd, of naar de vaders gezonden; 3. Pöitopitiana, dwergen, slechts $\mathrm{I} / 2$ meter lang; 4. Mawayana die een geluid als een pad (mawa) voortbrengen; 5. Kiapokoyana die 's nachts hun dorpen verlaten (kiapok toekan); 6. Kampoyana, die met of in het vuur leven (kampö gerookte visch of vleesch, of het roosteren); 7. Patakašiana, die 's nachts onder water gaan (patakaši een visch); 8. Leleyana, die 's nachts jagen en overdag tegen een boom hangen (lele vleermuis). Zie nog C 91, 156, 83, 1G4, 5G 500. Men vertelde mij voorts van „Oayana"'s die in het geheel geen aanraking met Negers en Blanken wenschen te hebben, waarmede wellicht bedoeld werden de in 1937 en 1938 gevonden Wama's in het brongebied van Oelemarie en

1) De Arawakken noemen dit vogeltje Masasikiri likin, M.'s (een geest) huisdier; waarschijnlijk is het de spookvogel Diplopterus naevius. Vgl. nog Crev 300 Aparai's raken in paniek bij het hooren van een vogeltje; en de Braziliaansche matinta-pareira, Tat 148, $2 \mathrm{Str} 518$; zie ook Te 76 de booze medicijnman zendt zijn kwaad als een nachtzwaluw naar het slachtoffer. 
Makroetoe, of ook nog anderen; vgl. ook C 83, 156 en zie nog Kusari's C 336, 342, 350 .

De wespenborden (Crev 249, C 244, 1G P1 II, 2G Taf II) stellen geesten voor; teekeningen op verschillende voorwerpen eveneens. althans in zeer vele gevallen, waarbij men echter teekent naar vaste traditie $^{\mathbf{1}}$ ).

Daar is vooreerst de ronde schijf van bijna een meter middellijn, maluana geheeten ${ }^{2}$ ), die in ronde huizen den nok van het dak van binnen afsluit. In verschillende kleuren zijn daarop afgebeeld aan weerszijden van het middelpunt een Kuluwayak, soms nog meer dergelijke figuren, en meestal een mensch en nog verschillende dieren. Voorts zijn ook op de plankjes van het dansrugsieraad ëki-apoyan, 1G P1 IV3, X6, 7, 2G 7, Taf XIX4, dergelijke figuren geteekend en eveneens soms ingesneden op bankjes (1G P1 VII2). De olok, de groote danshoed $(\$ 43)$ heeft veelal aan de voorzijde een bandje van vlechtwerk waarop een mozaiek van wit en zwart hoorn van toekansnavels, voorstellende Mekuom of een anderen geest. Soortgelijke meanderachtige figuren toonen de kralen sierschortjes der vrouwen (1G P1X17-21; fig. 18 is de Mekuom-figuur, 19 de Kueimö-figuur 20 kaikui, P1 II fig. 1 is Kuluwayak; foto's $1 \mathrm{G}$ P1 XIII4, 2G Taf XII, SK 136, 160). Ook vlechtwerk bevat zulke figuren, of het figuur wanahieku- (Heliconia-bloem) of nog andere (1G P1 VIII6, 1X8, 15).

Het vischkaak-motief (2G 8-9, SK 155) der blauwzwarte huidbeschildering met Genipa-sap, wordt eveneens in den arm gekrast voor succes op de jacht ( $\$ 21)$ en daar een vischkaak een der voorwerpen is, die men tot afweer van demonen ophangt ( $\$ 20)$ en de Genipabeschildering door Mope en Kuyuli is gegeven ( $\$ 7$ ), is het waarschijnlijk dat ook dit motief met magische bedoeling wordt aangebracht. Ook de kalipo-imirikut, pot-beschildering, is dikwijls een vischkaakmotief. (Het beschilderen van potten schijnt bij de Oayana's in onbruik te raken).

Gelaatsbeschildering $t$-epia-tse ( $e$ - zich, pia magie?) met roode en zwarte verf (1G pl XI) is üyaši (magie). Eveens is ïyaši: jaguartanden als halssnoer ( $1 \mathrm{G}$ pl I 8, 9, SK 184), en ook het koordje boven

1) Reeds Martyr 22-23, 76, vermeldde, dat Indianen de geesten die ze zagen, afbeeldden.

2) Overeenkomstige woorden in verwante talen beduiden „schild”. Dergelijke maluana's bezitten het Rijksmuseum voor Volkenkunde te Leiden, het Museum voor Ethnographie te Basel; afbeeldingen Crev 108, SK 157, 168 en beschrij . ving Normand 235, 246. 
den enkel, door Taponte en zijn leerling gedragen en door Taponte gemaakt, waardoor de demonen niet in de kuit kunnen binnenkomen.

Geijskes verwierf door ruil een door een kind gedragen snoer van schelpen en blauwe kralen; de moeder waschte het snoer wel een kwartier lang in de rivier: ,het kind zou anders een ongeluk overkomen".

Mede in verband met tal van mededeelingen omtrent andere Indianenstammen (vgl. Metr 178 en 4Nim) wordt het waarschijnlijk, dat alle opsiering van voorwerpen of lichaam der Oayana's verband houdt met de geestenwereld, althans oorspronkelijk daarvoor bedoeld is. Wij zullen straks hetzelfde vinden voor muziek en dans (§ 44). De Oayana toont bij dit alles wel goeden smaak en hij weet het schoone van voorwerpen of menschen of de natuur wel te waardeeren, doch kunst zonder magische bedoeling bestaat bij hen vermoedelijk niet.

\section{De hemelverschijnselen.}

$\S 12$. In de ruimtelijke wereld hebben geesten van de in $\S 11$ bedoelde soort, althans sommige daarvan, een soort uitstralingspunt in de sterrebeelden. Als het sterrebeeld aan den hemel staat (te middernacht culmineert ?) dan paart de betrokken diersoort ${ }^{1}$ ) C 223 heeft de namen der maanden gegeven, doch dat zijn niet anders dan namen van sterrebeelden.

Met veel moeite kreeg ik de volgende namen, hier zoo goed als het kon naar hun volgorde aan het uitspansel, gerangschikt:

inau Plejaden; kapao yalamatatpö (voormalige hertkaak) Aldebarangroep; yalaka?; pia oponpï (voormalig arendsnest) ?; ipetpiiin (dijbeenlooze) Orion; akalimaku (akalima spin)?; awokoku (awok hoen Crax) Zuiderkruis; twee jagers die dit hoen vervolgen $\alpha$ en $\not \beta$ Centauri; watau (visch Myletes sp.) kleine sterren Centauri; pakalaimö (groote reiger) Schorpioen; alazvataku, de oorsprong der brulapen (alawnta brulaap) Raaf of Delphinus; ololiku (ololi leguaan) Noorderkroon; honoleku (honole reiger) ?; kuliputpö (schildpad) $\beta$ Hercules?; yolokoku ,als een mensch" (yoloko natuurgeest, doodengeest) Hercules?; iri-tamu (drievingerige luiaard grootvader) ?; alukole (twee-

1) Dit geloof is algemeen bij de Indianen van Guyana, zie meP I 103, 2Roth 236. Vele mythen vertellen ervan, hoe, toen de paradijstoestand ophield, de geesten, mishandeld door de menschen, ten hemel voeren en sterren werden. 
vingerige luiaard) tusschen Noorderkroon en Zwaan; alimi (aap Ateles) Sagittarius?; išoimaku (išoima baardaap) Groote Beer? kapaoku (kapao hert) nabij Pegasus; kawata (soort waterschildpad) Wagenman? ëkeyeimeku (ëkëimë anacondaslang) Ophiuchus? Perseus ? ${ }^{\mathbf{1}}$ ).

De naam voor ster of sterrebeeld in het algemeen, is sirik $\ddot{e}^{2}$ ); Jupiter, of ook andere planeten en groote sterren noemt men sirikonko; dit zijn aanvoerders der sterren (vgl. konko broer der moeder). Venus, die tijdens mijn verblijf avondster was, noemde men Tapulakawa. De regentijdsterrebeelden van inau tot ipetpuin, of nog enkele meer, zijn kopö-tamu, regengrootvader; ololiku en andere zijn drogetijdssterrebeelden. Op een vraag over ipetpïin werd mij verteld (doch vaag en onzeker), dat yalaka diens schouder is, yalamata zijn kaak, риири zijn linkerarm, ololiku zijn rechterarm, ёkëyeimeku zijn buik, onoleku zijn navel, winau zijn lichaam of vleesch, stukgesneden.

De sterren zijn Oayana en als vuur; de medicijnman, die in de extase ,het pad”, d.i. den Melkweg ( $\$ 7$ ) begaat, ziet dat.

$\S 13$. De zon was vroeger Oayana; hij kwam in een boot en bracht alle voorwerpen en ook een zeer groote pad (vgl. § 7). Er was toen nog geen nacht. De zon ging weer heen en verscheen daarop aan het uitspansel. De zon is een kaikui die zich langs den hemel beweegt; op het hoofd draagt hij een prachtigen olok (vederhoofdtooi met straalsgewijze roode ara-vederen). Als zijn hoofd onder den horizon duikt, wordt het nacht; hij gaat dan onder de aarde door en als zijn hoofd aan de andere zijde weer bovenkomt, wordt het, dag (vgl. 2KG II 11).

$\S 14$. De maan was vroeger Oayana. Hij ging met zijn vrouw het bosch in en maakte een korf van wama (vlechtriet, Ischnosyphon). De vrouw vroeg ,wat is dat?” doch de man antwoordde slechts ,maak vuur aan”. De vrouw weende. De man deed haar in den korf gaan, reeg dezen dicht en lag hem op de barbakot (rooster) boven het vuur. Het was een mooie, jonge vrouw en daarom was zij vet. De man at een gedeelte van het vleesch op en deed de armen en beenen in een

1) De Aldebarangroep, de Plejaden, Orion en het Zuiderkruis dragen bij vele volken overeenkomstige namen; bij de overige sterrebeelden is er weinig overeenstemming.

$\left.{ }^{2}\right) \mathrm{Bij}$ karibische volken is sirika of siriku veelal in het bijzonder de naam van de Plejaden, het sterrebeeld dat het begin van het indiaansche jaar aangeeft. Het is mogelijk, dat de uitgang $-k u$ (C $223-k u r$ ) beduidt „,volmaakt”, of „schoon". 
draagkorf. Daarop keerde hij naar het dorp terug, waar hij na drie keer overnachten, aankwam. Het meegebrachte vleesch werd in de pepersaus gedaan. De schoonvader van den man vroeg: ,waar is de vrouw?" De man antwoordde ,zij is niet meegekomen”. Doch de schoonmoeder zeide: ,,ik zie voeten”. De man ging heen. De broeders der vrouw maakten pijlen en achtervolgden den man, die in spiralen omhoog steeg; zij schoten pijlen naar hem, doch raakten niet (C 555 de achtervolgende familieleden verbrandden en werden sterren). Die man is thans de maan en de zwarte figuur die men in de maan ziet, is het bovenlijf der vrouw die hij heeft opgegeten. ${ }^{1}$ )

Als een meisje rijp wordt, komt, zonder dat ze het bemerkt, de maan op een nacht bij haar en copuleert met haar, waarvan het gevolg is, dat het meisje de eerste menstruatie krijgt. Ik ben er niet zeker van, of men bedoelde, dat dit in het leven van elke vrouw slechts één keer geschiedt of dat het telken male voor de menstruatie plaats vindt. De maan makt het bloed van de vrouw en uit dit bloed ontstaat het lichaam van het kind; de ziel (akuali) komt van den vader. Andere mededeeling: bij alle geslachtsgemeenschap van menschen of dieren is de maan aanwezig; alle kinderen en dierjongen zijn door de maan gemaakt. ${ }^{2}$ )

Men vertelde ook: de nieuwe maan wordt voorafgegaan door een kleine ster, $i$-puit, zijn echtgenoote. ${ }^{3}$ ) Andere mededeeling : Sirikonko (avondster) is een oog van de maanvrouw, Tapurukawa (morgenster) is haar andere oog.

$\S 15$. Den drogen tijd noemt men këlin-këling $=$ cicaden (gesjirp), evenals bij de Tamanaco's.

De donder is yolok eu (geest muziek); de regen is ook een geest; regendruppels noemde men kopö pitani $=$ regenkinderen, dauw tutak. ${ }^{4}$ )

1) Waarschijnlijk is dit een der vormen van de ver verbreide mythe hoe de maan incest pleegde (2KG II 12, 276-7, Roth 255 enz., soms als begin der tweelingmythe. De maan geldt ook wel als hermaphrodiet, 2BR 151). Het schieten met pijlen, duidt wellicht op den pijlenketen als hemelladder, zie noot bij $\S 6$.

2) Dergelijke opvattingen bij vele Indianenstammen. Zie ook de Kaschinauamythe 3KG 232-41. En vgl. Uitoto Preuss 94 De roode verf van Bixa Orellana behoort de maan; Uuupes-stammen $1 \mathrm{Str} 670$ de medicijnman neemt caragiri (roode verf van Bignonia Chica) van de maan.

3) Iets dergelijks $2 \mathrm{KG}$ II 12 , III 282.

4) Zie ook $\S 11$; bij vele volken van Guyana geldt de dauw als speeksel of urine van sterren. 


\section{De püyai (medicijnman).}

$\S 16$. Het püyaischap is niet een betrekking, doch een vermogen; van sommige mannen zegt men, dat ze een weinig püyai zijn, van anderen, dat ze een sterke püyai zijn, en bij het spreken over den Molokot en andere geesten, zeide men dikwijls „,vroeger” schouwden de püyai's die. Misschien is dat vermogen tot schouwen nog niet verdwenen, althans, Taponte, zelf püyai, vertelde mij op een wijze alsof hij het zelf had doorgemaakt, hoe men het pad (de Melkweg, vgl. 2KG III 173) gaat en dan bij de geesten is. Een veel bij de Oayana's vertoevende creool vertelde mij, dat Taponte in staat was, te vertellen wat er bij mij thuis in Europa voorviel, en dat als ik mij bijv. door hem zou laten behandelen en hem niet zou betalen, hij mij zelfs daar een kwaad zou kunnen toezenden.

$\mathrm{Om}$ de geesten te laten verschijnen, d.i. in het bewustzijn, of althans binnen bereik te krijgen, is het voldoende een indiaansche sigaret te rooken en de oproepspreuk te zingen. Maar dat heeft slechts gevolg bij degenen die er een natuurlijken aanleg voor hebben, en zelfs deze maken nog een opleiding door, waarbij tabakswater wordt gedronken en dieet gehouden (volgens Taponte drinken alle stammen van het binnenland voor dit doel tabakswater en andere plantensappen). Den geoefenden püyai verschijnen de geesten, als hij in de hangmat ligt te rooken, volgens C 207, 223, in den droom.

- De medicijnman bedient zich van de krachten van zijn helpende geesten. Mijn vriend Tuwoli $(\dagger 1907)$ was, zooals ik thans eerst vernam, een zeer sterke püyai, en de geest-waarmede hij verbonden was (verm. de opperste van den geestentroep waarover hij kon beschikken), was de poineke-tamu, de zwijnen-grootvader; ook zijn zoon Kasirinale was met dien geest verbonden; gewoonlijk, zoo zeide men, heeft de zoon denzelfden geest als de vader. $\mathrm{Na}$ den dood van Tuwoli werden de zwijnen schaarsch ${ }^{1}$ ).

1) Algemeen wordt aangenomen, dat de medicijnman op bovenzinnelijke wijze macht heeft over dieren, zie 1 Roth 341 en perP nos. 49, 78. Hoe dit, naar Indiaansche opvatting, mogelijk is, moge blijken uit de volgende mededeeling van Cuna-Indianen (Panama; Nord 464) : „L'on sait que le poivre de Cayenne,, en brûlant, dégage une fumée âcre qui provoque un toux terrible. Le Néle (medicijnman) peut se glisser sous une couverture à l'abri de laquelle on consume de cette substance sans que la fumée le gêne le moins du monde. Cet exploit lui est possible parce qu'il connait l'origine du poivrier. De la même façon, certaines personnes sont capables de tenir dans la main un fer rouge ou d'empoigner des serpents venimeux, etc., à condition de connaitre l'origine du fer et des serpents”. 468 „Autrefois, et peut-être encore à présent, les néles recevaient la 
De medicijnman mag nooit het vleesch van de diersoort eten, welker oorsprongsgeest zijn beschermgeest is. Er zijn velerlei diëetvoorschriften en met ijzeren wilskracht houdt men zich aan het diëet (zie C 210).

[Ahl meldt: De kleine snip waikiki mag men niet dooden; zij zou naar God gaan en ook gij moet sterven. Een jongen mag geen schildpadvleesch eten, want daardoor zouden, evenals bij den schildpad bij het loopen, zijn knieën te ver doorzakken; hij zou niet meer goed kunnen loopen, niet kunnen jagen.

Ahl meldt van den medicijnman Painawari: hij is de zoon van een grooten püyai. Deze heeft zijn jongen, toen hij ongeveer 4 jaar oud was, boven den neus tusschen de wenkbrauwen laten steken donr een bijzonder soort wesp, kumará geheeten. In den tijd dat hij leerling was, mocht hij den droesem der kaširi (gegiste drank) niet drinken en mocht de apomali (hoofdkrans van toekanveren) niet dragen. Doch de vader maakte voor hem een kuluzra, hoofdband van maripapalmbladtong en schreef daarop in vurige letters het woord püyai, zijnde een menschelijke figuur, die ingebrand was.]

$\S 17$. Voor een belangrijke ziektebehandeling, richt men onder het dak van een huis een tijdelijk hutje van palmbladeren op, mumnë of yolok-ene-top (geest-zien-plaats of -werktuig) geheeten. De behandeling begint als het geheel donker is, en alle licht wordt gedoofd. De medicijnman roept door een elemi (tooverzang) zijn helpende geesten op; hij roept er talrijke op, doch slechts één daarvan is het, die den yolok zal verjagen. Een rammelaar is bij de Oayana's niet in gebruik. Bij een dergelijke behandeling hoorde $\mathrm{ik}$, hoe men de bladeren van het huisje nu en dan deed ritselen, op den grond stampte en een geluid voortbracht als het knallen van een kurk. De medicijnman zong

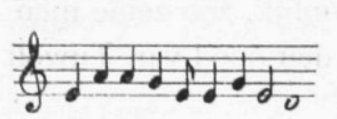
een welluidende elemi en een vrouw (niet de patient) antwoordde den geest met $\ddot{e}-\ddot{e}$ enz. De medicijnman zoog het kwaad uit (zie hieronder, geestenpijl) en zou betaling krijgen als zijn behandeling tot genezing leidde ${ }^{\mathbf{1}}$ ). Crev 299 en C 208 vermelden, hoe de medicijnman met een klein boogje en pijl den ziekmakenden yolok ,doodschiet”

visite des bêtes de la forêt. Ils parlaient avec elles comme si c'étaient des gens. Le Néle alla dans un des compartiments de la hutte (surba) et se mit à penser à l'origine des animaux, puis il chanta. Ce fut parce qu'il connaissait le secret de leur création qu'il put les apprivoiser".

1) $\mathrm{Bij}$ de verwante Cumanagoto's kon, als de zieke stierf, diens familie den behandelenden medicijnman dooden (B1 57). 
(zie ook $\S 18$ ), C 206, hoe hij het kwaad met de handen uit het lichaam van den lijder trekt, het op den grond werpt en erop spuwt.

Medicijnzang van Taponte, in den vooravond zittend naast de hangmat van een ziek kind:

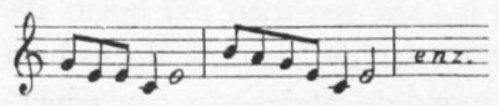

[Ahl zag hoe een Indiaan met een brandende sigaar den medicijnman Painawali naderde en hem die sigaar aanbood. Painawali nam de sigaar aan, rookte, en een kwartier later stond hij op en ging de zieke vrouw van den sigaaraanbieder behandelen. Crev 299 hoorde, hoe de medicijnman bij de behandeling den kaikusi-piai (tijger-geest), meku-piai (capucijneraap-geest), matapi-piai (kassavepers ?-geest) opriep; daarna liet men den zieke in het hutje komen en de medicijnman beblies hem met tabaksrook. De zieke moest vervolgens dieet houden: pakira (zwijn), powieshoen, groote visch, kasjiri waren hem verboden; Ahl maakt melding van het voorschrift van onthouding.]

$\S 18$. De ziekten onderscheidt men in tiephe (koortsrilling, verm. meest malaria), kuamai (verkoudheid, in erge gevallen longontsteking, treedt epidemisch op ${ }^{1}$ )) en wellicht andere en y'olok pléu, geestenpijl, waaraan men elke inwendige pijn toeschrijft. Elke püyai heeft een klein boogje, waarmede hij een geestenpijl kan afzenden om een slecht mensch te straffen, doch de booze püyai ook met kwade bedoelingen. Hoe dit precies geschiedt, heb ik niet gezien, doch men vertelde mij, dat een yolok het vermogen heeft, een klein voorwerp tot iets groots te doen opzwellen. Inwendige pijn schrijft men altijd toe aan yolok-pléu, toegezonden door een boozen püyai, steeds iemand aan een andere rivier, soms met name genoemd. [Volgens Ahl wordt ook een val uit een boom toegeschreven aan een boozen püyai, die met een boogje (tawioma) en pijltje (wamaimë, verm. vlechtrietgeest) hem geschoten heeft.] Ik zag stekels van het boomstekelvarken, die als yolok pléu poti (demon-pijl-punt) werden gebruikt.

De goede medicijnman die den door een geestenpijl getroffen en ziek geworden Oayana behandelt, roept zijn geesten op, zuigt op de pijnlijke plekken en brengt ten slotte een stuk glas, splinters van den komboepalm of van bamboe, als anderszins, te voorschijn. Taponte, bezadigd en verstandig man, vertelde mij op een ochtend, dat hij den

1) Kahn onderzocht 70 Oayana's van de Tapanahoni (? er wonen daar geen 70 mannen) op vatbaarheid voor tuberculose; bij allen was het resutaat negatief. 
vorigen avond bij drie patienten een geestenpijl uit de borst had verwijderd. In allen ernst toonde hij mij twee dier pijlen, waarbij ook het publiek, waarvan de meesten evenmin domooren, volkomen ernstig was. Het waren verdroogde snavels van een reiger. ${ }^{1}$ ).

Min of meer van denzelfden aard is, wat een man mij opgaf als oorzaak van de ziekte van twee menschen aan de Litani. Volgens hem had een Oayana van de Jari, met den mond de Ateles-aap, capucijneraap, mamhali (Psophia), powies (Crax) enz. afgebeeld; die geesten komen dan in het ingewand van den betrokkene en deze gaat braken en krijgt buikloop en sterft. Een booze püyai kan ook maken, dat iemand die in het bosch is, gaat zweeten en een gevoel krijgt, of peper hem brandt (iets dergelijks $1 \mathrm{Nim} 354$ ); hij springt in het water gelijk een tapir en den volgenden dag spreekt hij als een tapir. De booze püyai kan ook maken, dat iemand gaat spreken als een aap, als een arend. Daarna verslindt de booze pïyai zijn slachtoffer. Zie nog C $198,208^{2}$ ).

Toen er een keer regen en wind was, zeide men, dat dit wellicht veroorzaakt werd door een zoo juist gestorven medicijnman wiens lichnam. gecremeerdi was.

1) Iets dergelijks wordt van talrijke volken in Zuid Amerika en daarbuiten, gemeld. Tessmann beschrijft hierop lijkende gebruiken, en daaruit laat zich vermoeden, dat de medicijnman cen of meer van zijn eigen lichaamsgeesten min of meer als waren ze van stoffelijken aard, kan uitzenden. Het schieten van een pijltje is wellicht bedoeld als het toevoegen van „schiet-, tref- en binnendring-geest" en het uitzuigen van een scherp voorwerp, als hetzelfde proces in omgekeerde richting. Is deze verklaring juist, dan is het afschieten en het uitzuigen gewone magie en wordt het begrijpelijk, dat al die volken op dezelfde wijze handelen en het voor hen volstrekt niet dwaas is.

2) De Kalienja's kunnen op drieërlei wijze met de geestenwereld verbonden zijn: De tabaksmedicijnman beschikt over den troep der tabaksgeesten (vooral vogelgeesten), wier anvoerder is Tukayana, in koningsgieren- of menschengedaante; bij de inwijding drinkt de noviet tabakswater, eet tabaksblad, rookt sigaren. De takini-medicijnman (iets minder machtig) beschikt over den troep der takinigeesten, wier anvoerder is Yulamale, de Ateles-apen-grootvader; bij de inwijding drinkt de noviet het sap van den takiniboom. De pepermedicijnman (of medicijnvrouw) beschikt over den troep der pepergeesten, wier aanvoerder is Imazvari, de wilde zwijnen-grootvader (bij andere volken is dit de naam van een aardgeest); bij de inwijding eet de noviet spaansche peper en moet in het bosch gaan op een plek waar het waait. De pepermeester heeft geen rammelaar, werkt alleen met den mond; zijn verbondenheid met het bosch, den wind en de wilde zwijnen, wijzen er duidelijk op, dat hij in het bijzonder verbonden is met de bosch- en aardgeesten (men zegt: met de aard- en onderwatergeesten) wier aanvoerder is Kurupi (zie voorts noot bij § 43). De booze toovenaars, waarvan Gillin 147, 186 spreekt, zijn blijkbaar dergelijke peper-medicijnmannen. En hiermede komt min of meer overeen het ,met den mond afbeelden” waarvan een Oayana mij vertelde. 
Bekoringsmiddelen en afweermiddelen.

$\S 19$. De Oayana's gebruiken knollen van aroideën (misschien ook van andere planten) hemüit geheeten, om er een voorwerp of een mensch mede te bestrijken en zoo bepaalde eigenschappen in dat voorwerp of dien mensch te doen overgaan, of reeds aanwezige eigenschappen te versterken ${ }^{1}$ ). Ik noteerde: a) middel ter genezing van slangebeet; b) pakira-hemite voor de jacht op pakira (wild zwijn), er wordt stinkklier van een pakira bijgevoegd; c) maipuli-hemiti voor de jacht op tapir; d) ka-hemüit voor het schieten of met den haak vangen der visschen pašina, watau, ašitau en molokoimë (vermoedelijk alle Myletus-soorten); men schraapt wat van den knol af en smeert dit op boven- en onderarm, boog en ondereind pijl of vischlijn; e) knolletjes, turala genaamd, om een kindje ,snel te laten groeien, gelijk een tapir-jong”; f) bekoring tegen de Oayarikulé's ( $\$ 39$ ) ; g) de tahek-top (copuleeren-werktuig) gebezigd door een man die een vrouw wil bezitten. De man smeert iets van dezen knol, vermengd met roekoeverf op zijn onderarmen en als hij dan de vrouw roept, wordt ze onweerstaanbaar aangetrokken. Of, als dat niet helpt, smeert hij iets van het middel op haar buik onder den navel en den volgenden morgen zal ze voortdurend lachen. Of hij speelt op de fluit een zoete melodie voor haar (vgl. Iz 314); onder- en boveneinde van die fluit heeft hij tevoren met het middel bestreken. Of hij duwt haar het uiteinde van die fluit in de zijde. C 109 vermeldt : „les tayas (aroideën) qui font aimer, les tayas qui exorcisent le Yolock, les tayas qui rendent fou, les tayas qui tuent lentement, les tayas qui tuent vite”, C 208 .,Il y a des tayas pour dresser les couatas. Il y en a pour faire revenir la famille qui est au loin et qui, dès lors, ne fait plus que pleurer en pensant à vous".

$\S 20$. Veelvuldig past men yolok ipiti, geest-(afweer)middel, toe. Ik noteerde: a) de koya, gehalveerde harde pit van een vrucht (Britsch Guyana hakia seed, volgens 2Roth 717 van Tecoma sp.), wordt wel door kinderen aan een halssnoer gedragen; het is iyaši, piaima-top, möh piasi ; wie een koya draagt is onzichtbaar voor de

1) Overal in Guyana kent men zulke middelen. Door het onderzoek der Penards bij de Kalienja's zijn wij uitstekend ingelicht omtrent de opvattingen hierover (meP I 177 vgl. en zie ook 1Roth 281 vlg., Gilin 180 vlg.). Het gaat om de krachten of geesten die het innerlijk der natuur zijn en die ook de mensch in zich heeft. De plant welks knol men gebruikt, gelijkt meestal in het een of ander opzicht op de diersoort als anderszins, welks beginsel men in dien knol aanwezig acht.

D1. 100. 
yolok's; mijn vriend, de hoofdman en medicijnman Tuwoli gaf mij in 1904 ten afscheid zoo'n amulet mede; b) in een hut van een ouderen man ( alepaimë of van simali (Cedrela odorata) gesneden afbeeldingen van knotsen, met koya's aan een katoenen draad gebonden, waarvan men zeide dat het tаmu yoloko-n, tamu piai of yolok epit was (tamu's geesten, geestenmiddel) en dat het, bij een zieke opgehangen, maakt dat als een booze yolok komt, deze wordt teruggedreven; er hing in dat huis ook een opgestopte kalau (vogel Ibycter), die ,tuwök" was en „watahatp $\ddot{o}$ ”; c) het ronde riviersteentje waarmede men de aarden potten polijst weert ook demonen af; d) bij de hangmat in den grond gestoken roerspanen en aan een stijl van het huis opgehangen voorwerpen (botjes van Psophia en capucijneraap, hoorns van een grooten kever, de kaak van een pirai-visch) dienden om te beveiligen tegen den yolok van een overleden medicijnman, welks weduwe onlangs op het dorp was gestorven en verbrand, waarna die yolok 's nachts spookte; e) met hetzelfde doel: oude katoenen draden, vermoedelijk van een uitgeplozen hangmat, gespannen 1 meter boven den grond als magische barrière tusschen het hutje van die weduwe en het huis waar men sliep; ook dit was , weratahatpö"; naar ik meen waren tevoren tooverspreuken over die draden uitgesproken (vgl. $4 \mathrm{Nim}$ $88)$; f) C 180 besproeien met water waarover een tooverspreuk is uitgesproken; g) C 180, 198 1G 27 Spaansche peper branden, zie ook § 48 en Crev 269 bij de bereiding van curarepijlgift eet men als voorzorg Spaansche peper, en vgl 1Roth 293, 298. h) Min of meer van denzelfden ard is vermoedelijk wat Geijskes in 1939 aan de Oelemari zag: van een hoogen boom hing een touw (liaan) af, waaraan, van boven naar beneden gebonden: het schouderblad van een capucijneraap, een stekelplant, takjes van de slingerplant ulukieimë, snavels van een toekan, een verdroogde passiebloem, ribben en stuk wervelkolom van een gordeldier, een bundel powiesvederen waaraan bloemtrosjes en botjes van den Ateles-aap, toekansnavels, papegaaiveertjes, Ateles-botjes, stuk wervelkolom van een Ateles-aap. Het geheel noemde men musi-kenapi (vgl. 1Roth 229, 1KG I 237). i) Ten tijde dat de hoofdman Malataiwa door de Bonni-Boschnegers in gijzeling was weggevoerd, hing er op zijn dorp aan een schuine bamboestok een mannelijke en een vrouwelijke pop, gesneden uit zacht wit hout. Crev 301 maakt melding van een pop voorstellend „yolok” op een Aparai-dorp.

$\S 21$. Aan geneesmiddelen heb ik opgemerkt : bij oorpijn water van 
de liaan ëtpapanali, dat men in de ooren van den zieke liet druipen; idem bij longontsteking van de liaan siwiman (Negerengelsch dia tetei); aftreksel van kruiden; bij koorts aftreksel der bast van de groote boomen etaglan of walapiti; het spinsel van mieren, met de mieren erin; dit is alles yolok pléu epit, geest pijl geneesmiddel. Bij een zieke die het koud heeft is soms een pot smeulend vuur onder de hangmat geplaatst, C 206 noemt ,des frictions, des cataplasmes, des infusions pour boire ou laver, des bains de vapeur, avec les racines, les fleurs, les feuilles, l'écorce de diverses plantes, l'eau de diverses lianes, l'oignon de certaines plantes bulbeuses" en voegt toe: „Quelques-uns de ces piayes (medicijnmannen) connaissent réellement fort bien les propriétés, parfois étonnantes, de quelques simples de leurs forêts". Taponte zag ik in den namiddag zijn rondgang bij de zieken maken en voorschriften voor de behandelig geven.

Een klein meisje droeg om den hals akuli-pana-tepu, hoorsteentjes van de agoeti, als middel tegen de kiespijn van haar moeder ${ }^{1}$ ).

Een vrouw droeg om den pols een snoer katoen, haar gegeven door een Aparai; dit was inik-top, slaapwerktuig.

Als men op de jacht herhaaldelijk misschiet, dan krast men zich in den arm een figuur (het sokane-patroon, 2G 8 fig. 16) ; er komt bloed uit; men vast en eet slechts kleine stukjes kassave. Daardoor krijgt men de kracht om een sterken boog te spannen en zal den volgenden dag raak schieten. Daarna mag men het bloed afwasschen (iets dergelijks Bl 57, 1Roth 278, 2Roth 706-7, 2KG III 122). Voorts kan men zich geschikter voor de jacht maken, door mieren- of wespenproef te ondergaan, waarover nader in $\S 41$. Ook schijnt door slaan met een palmbladspruit magische kracht over te gaan op den geslagene (2G 19, C 544).

$\S 22$. Ik zag hoe een vrouw en kinderen in een huis kleine stukjes opgedroogde pottebakkersklei aten, hoewel er geen hongersnood was; ik proefde ervan; het was ietwat zanderig en zonder smaak.

\section{Magische spreuken.}

$\S 23$. De magische spreuken of gezangen, elemi, zijn afkomstig van de voorouders of geschonken door Kuyuli. Die welke hieronder vermeld zijn, worden door alle Oayana's toegepast. De medicijnmannen

1) Ook bij de Kalienja's dragen kinderen gehoorbeentjes van de agoeti aan een halssnoer; de hoorbeentjes van de zeekoe dragen zij als middel tegen stuipen (eAhl 75, 547). 
hebben ook elk een of meer zulke spreuken, die als het ware persoonlijk eigendom zijn; bij de Aparai's heeft, naar mij verteld werd, elke man, vrouw of kind, een eigen spreuk.

Ik woonde bij, hoe een man een kindje, dat een wond aan den voet had, liet loopen, waarbij hij een elemi opzegde. Hoe een grootmoeder haar kleinkindje, dat een begin van huiduitslag had, baadde, onder het opzeggen van een elemi. Hoe een vrouw die een opengebarsten gezwel of steenpuist had, liggende in de hangmat, elemi uitsprak over een kalebasje met water, afgewisseld met blazen op dat water, waarna ze er hoofd, borst en het gezwel, mede besprenkelde, wat, naar zij mij later mededeelde, uitstekend geholpen had. Een man die op reis was geweest en toen hij wegging veel schurft of dgl. had, kwam grootendeels genezen terug; hij had zichzelf met elemi behandeld. Men bood mij aan, mijn armwond (Leishmania cutis) te behandelen met elemi. Ik moest op een bankje gaan zitten en het verband afnemen; een oudere vrouw kwam er op een lager bankje naast zitten en sprak 10 à 15 minuten elemi uit itë-k ëlikü, Kuyuli-pona, ga heen wond, naar Kuyuli, enz.; ook de namen Mope en Pëlikaman hoorde ik uitspreken, en telkens blies of spuwde ze op de wond; het valt niet te zeggen of het iets heeft uitgewerkt, daar ik kort daarna een Europeesch-medische behandeling onderging. Zie voorts C 205-7.

Met moeite heb ik stukken elemi opgeteekend; men deelde ze mij, vlug sprekend, op fluistertoon mede, en liet er zich voor betalen. Hier volgt wat ik noteerde, met de vertaling, die ik met behulp van enkele uitleggingen, zoo goed mogelijk opstelde.

Bij deze spreuken wordt de ziekte(geest) verzocht heen te gaan en genezende natuurkrachten worden opgeroepen. Men verklaarde mij, dat de termiet(geest) wordt opgeroepen, omdat de termieten een scheur in hun bouwsel snel weder dichtkleven, de otter(geest), omdat de otter zich niet kwetst aan de rotsen, slangenneus en kapiwara-snuit, wijl deze goed stevig weefsel hebben. Iets dergelijks, naar het mij lijkt, in de door Sp 188 bij Aparai's genoteerde spreuk en in de spreuken der Taulipang's, 2K III 219 vlg. Die Taulipangspreuken vermelden ook den mythischen oorsprong van de kwaal en van de genezing. Nauw verwant aan deze geneestooverspreuken, lijken mij de gezangen die de Kalienja-novieten zingen bij de opleiding tot medicijnman (pP, perP).

$\S 24$ Een man liet een kind met een voetwond loopen, en prevelde daarbij : 
ašitate ašik

imolota-tome-püira

talasipo-püine

Umuitipüyi

titikapu isemüi

mokë Kanáyékë ga heen ${ }^{1}$ )

rotten-opdat-niet

niet verderven ${ }^{2}$ )

vurige (prikkende, jeukende)

geest ${ }^{3}$ )

zich maken hechten (heelen)

kom K.! ${ }^{4}$ )

$\S 25$. Zang van den medicijnman, zittend naast de hangmat van een ziek kind.

uleti yetunu-lu

Aponani mëkëlë

yoloko-na pleu-potili

tawali tamui

kuletili-kë

Apona nep-kë

enokilime

(yolok atamisili)

(dit is:) yolok elemi kwaad pijn

A. kom!

demon pijlpunt

..... tabak

goed maak!

A. breng!

zend

de demon gaat

demon zang

$\S 26$. Op mijn vragen zeide men:

ëtapo-kulële-zuai yolok

yuhumunin

tiephe makina

uamera makina

ëlimi mimirikei: hangmat schommelen ik-doe kassavegeest (?)

koortsig helaas

onwel helaas

schrijf het toovergezang op:

Als de voet door een pijl (demonenpijl) is getroffen, zegt men:

ulipule ëkëši

ëtunu kaline

Apone k-waše

ëtunu kaline

Kuletate-ă̌e kwaad $\ldots{ }^{5}$ )

pijn wegnemend

A.'s tooverkracht ${ }^{6}$ )

pijn wegnemend

K.'s (?) tooverkracht ${ }^{7}$ )

Als de borst door een pijl is getroffen, zegt men:

1) Deze beteekenis werd mij opgegeven; misschien : „spoed je, toovermacht”.

2) Er werd gezegd ,als de kaaiman”; misschien verwant aan ašira verdrogen, verdorren?; -püine, -pona ,zonder"?

3) Of Omüitipiii; „,is een klein meisje, in den hemel”.

4) „Een groote vogel, als een eend”.

5) ulipule misschien ule pijl püle pij1, met de beteekenis van "demonenpijlen”.

6) Onzeker of Apone de naam van een geest is; vgl. $\S \S 25,33$.

i) Onzeker of Kule de naam van een geest is. 
etunu kaline

plë ulëpule

ëtanamamuyai pijn wegnemend

pijl kwaad

zich oplichten

$\S 27$. Als men een zieke behandelt, zingt men (t-elemika-i) het volgende, waarbij men den zieke met tabaksrook beblaast en aan het slot fluit.

\begin{tabular}{|c|c|}
\hline Sirikonko ïlipile & 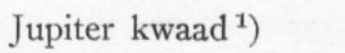 \\
\hline Nuпиӧ ilipile & Maan kwaad \\
\hline $\begin{array}{r}\text { ašitate alinö } \\
\text { ölipili }\end{array}$ & $\begin{array}{l}\text { ga heen witte klei } \\
\text { kwaad }\end{array}$ \\
\hline ašitate aše & ga heen \\
\hline Sirikonko ilepili & Jupiter kwaad \\
\hline $\begin{array}{ll}, & \text { etatelime } \\
, & \text { irupule }\end{array}$ & $\begin{array}{ll}, & \left.\text { vernieuwen }{ }^{2}\right) \\
, & \text { kwaad }\end{array}$ \\
\hline
\end{tabular}

$\S 28$. Bij een verbranden arm spreekt men:

Zang

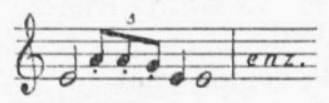

ilikele Nunü

Sirikonko Nunü̈

tipikaluë azeulupïle

imatopona

he Kuyuli-pona

he Kokaline

he Kuyuli-pona

he Mopo-ponal

he talašipopo

he talašipona

he Mopo ponalo

Kuyuli ulipule

he talaši popona

he wapot illipule

he imata-puin

he Kuyuli ašin

he imata-la kwaad (of huidwond ëlik) Maan

Jupiter Maan

ontvelling je kwaad

rotten niet

he Kuyuli-tot ${ }^{3}$ )

, K. (?)

, Kuyuli-tot

, Mopo-tot

, niet verderven

,. niet verderven

," Mopo-tot

Kuyuli kwaad

he niet verderven

", vuur kwaad

„, rotten-zonder

, Kuyuli tooverkracht

, rotten-niet

1) Het is mogelijk, dat men hier uitdrukt, dat de geest der planeet Jupiter de kwaal heeft gezonden, of deze kwalen indertijd in de wereld heeft gebracht; maar ik durf niet zeggen, of dat inderdaad bedoeld wordt. Er zijn meer van dergelijke versregels.

2) Onzeker; nieuwe maansikkel $=$ numuō tewat-iramoi.

3) Misschien is bedoeld „geest die tot Kuyuli opstijgt", zie § 32 . 
he Kuyuli ašin

he talašipopona

he imata-tozve-pola he Kuyuli tooverkracht

", niet verderven

, rotten opdat niet (?)

$\S 29$. Bij een gebroken vinger zegt men:

ašikoko aše

etatilimai

vernieuwen

Sirikonko waikuleme

he talašipapone

he tamulu kapone etatilimai

he kulamalime

Nunuö ilipile

he talašipopone

he Sirikonko manale

he Sirikonko male

he tapulu kono monyi

he erašimapoinpö

he talašipopone

$\S 30$. Bij een messnijwond:

mata-topo-la

he Kuyuli ponalo

he teotokapu šin

he akiši ïlipele

he teotokapu šin

he ou kuleuli

he eu yetunu kalime

he imate ...

he .....

teotekapu šin

he uyekoma kalime

Jupiter ....

he niet verderven

" grootvader hemel vernieuwen

,, mooi worden (?)

Maan kwaad

he niet verderven

„, Jupiter gevlochten zeef (?)

, Jupiter ...

,$\left.\ldots{ }^{1}\right)$

,$\ldots$

, niet verderven

rot-veroorzaker-niet

he Kuyuli-tot

, zich hechten dit

," bij $1^{2}$ ) kwaad

zich hechten dit

he ...

, pijn wegnemen

,, verrotten

,

zich hechten dit

he ....

", niet verderven

heu talaši popona

$\S 31$. Bij een slangebeet spreekt men:

he tapuletme

he ...

he kapu tamulu

", hemel grootvader

he talasi....

he kule....

he tewotukapu sin

sneki ${ }^{3}$ ) hilüpole (of ulupüle) slang kwaad

1) Men zeide dat monyi beteekende $k a p u=$ hemel.

2 akiši $=$ negerengelsch aksi, bij1.

3) sneki $=$ negerengelsch slang. 
$\S 32$. Andere medicijnliederen:

etatease imata-tohme-püla

\section{ašitate}

mohkö Kanayekë

aširame-ka-topo

ipopüila y-ešike

mohkö Malapitua

mokö Komalakë

püyaši Kuyuli-pona

etunamo topo

mohkö

imahtapuinomo

mohkö Tonalike

Kumalaka Tonalike

hayo ${ }^{4}$ ) tepunumašimü

ëkëyuliylip-ka-topo

$\S 33$. Bij slangebeet:

emnamoptapiron

kapiala emnamopitilin

ëzulipülin ka-tome

ayo henokü yase

ayo eulipüle-ka-topo

malapüla mühamo (-samo)

ayo hëwenoke-topo

ayo ëtalašipopüine

imata-tome-püla aoli-püla-yeh-

tohme

aolipüla Malapitua

moköy Yawawa

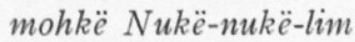

talaši popüine

moke Silišiliu ga heen (naar je dorp benedenstrooms) ${ }^{1}$ ) laat niet rotten ga!

Kom K.

verdor-wegnemer

niet-goed omdat

kom M. ${ }^{2}$ )

kom K. ${ }^{2}$ )

toovermacht Kuyuli-tot

een beetje water drinken

kom

dat het niet rotte

kom T. ${ }^{3}$ )

K. T.

hayo vleesch hechten

slang-kwaad-wegnemer

(slang) neus-breede

watervarken-neuspunt

om het kwaad weg te nemen

ayo zend tooverkracht

,, kwaadwegnemer

niet als zij

ayo wegzender

,, niet verderven

rotten-opdat-niet

.... M.

kom Otter

kom Termieten

niet verderven

kom S. ${ }^{5}$ )

1) D.w.z. ga terug naar het geestenland.

${ }^{2}$ ) Een hoog vliegende vogel; vgl. Kalienja „de vliegende puyai-geest Kuwamalaka, die zijn slachtoffers miauwend den nek breekt" (perP 55; 1Roth 349 Kwamaraka).

3) Een kleine hoog vliegende vogel; vgl. Kalienja tanalike (pP 638).

4) hayo of ayo voorvoegsel ,het moge, het geschiede"?

5) Een kleine vogel; vgl. silir Cotinga. 
ašitate ase (eašin) mohkë Kuyuli aulitpö nule mokü Lapona enoke-yašin here apaikalime

etunama-topo Kumarake tuna

tuna eukin

talaši popüine ilinai wai

Omuitipüi

ilomenak yetun etumhak molopokem eremike šin

$\S 34$. Slangebeet:

ëkëi wïlipüli

ülipkatopo emna-mo-solono eu ikupayinu

ayo talasipopüine

ököiyu ülipüli

ököiyu Kule ule püyaše

ayo Kuyulipona

ayo Mopo ülipüli-n

eulanaw

ayo eweyulenë

ayo mohkë Kilu

ayo ayulame

ayo talašipopüina

ayo etukalime

ayo matapuinomo

ayo muine $\ddot{e}$-pata

ulo imatapuinom

ayo Omüitipüi

ayo holili-ka-top

ayo Kuleuli ase

ayo aypakalime

ayo sere aypakalime

ayo iyetunole

ayo hetunkatopo ga tooverkracht

kom Kuyuli's woord maken:

kom L. ${ }^{1}$ ) zend tooverkracht

dezen pijl verwijderen

een beetje water drinken, K.'s

water

water ik ook (?)

niet verderven witte klei

Vurige geest

naar de vlakte mijn pijn pijnlijk

daartegen zing dit

slang kwaad

kwaad-wegnemer neus-vel (?)

uitpersen (?)

ayo niet verderven

slang kwaad

slang K. ${ }^{2}$ ) tooverkracht

ayo Kuyuli-tot

,, Mopo kwaad

woord

ayo je woord

,, kom K. ${ }^{3}$ )

,, je woord

, niet verderven

, pijn wegnemen

, dat het niet rotte

,, ginds je plaats (d.w.z. ga heen !)

... dat het niet rotte

Vurige geest

bederf wegnemer (?)

ayo $\mathrm{K}$. toovermacht

, pijl (palali) verwijderen

,, dezen pijl verwijderen

, het prikken der wond

, pijnwegnemer

1) Vg1. § 25, 26 Apona; misschien het karibische woord *arapono, eend.

2) Onzeker of Kuleule de naam van een geest is

3) Een der toekan-soorten. 


\author{
ayo hiloptakenma \\ ayo hiye... \\ ayo Kumalaka ülipüli \\ ayo ëweremika-top \\ ayo hulipokatopo \\ ayo talašipopuine \\ ayo hemnamoptapiron \\ ayo euputpulë \\ aypüle ülepole \\ ayo ëyatokolele \\ ayo ëyatapaitkatopo \\ ayo šiši ule-ule-na \\ ayo mohkë \\ hëupatali \\ ayo. . Awalimuit \\ ayo ülipoya üaše \\ ayo ëwenok-top Alulama \\ ayo ëwenok-topo-le \\ ayo hënёmё-topo-le \\ ayo henok-topo-le \\ ayo hewenok-topo-le \\ ayo Hemaluteimë \\ hayo Piši-ase \\ ëzveulena \\ hayo mohkë Lopoko \\ koyeremi-šike \\ hayo hëwetate-topo
}

ayo er binnenin

, . .

, K. kwaad

,, je medicijnliedzanger

, kwaadwegnemer

," niet verderven

, neuspunt

," mijn hoofd

, pijl kwaad

, pijlspits

, pijlwegnemer

, zonnepijlen (stralen ?) ${ }^{\mathbf{1}}$ )

,. kom

je dorp

ayo A. ${ }^{2}$ )

,enok püyasi müya” zend de tooverkracht ginds

ayo je wegzender $\mathrm{A}^{3}$ )

„, je wegzender

,, je ziener (?)

, je wegzender

, je wegzender

, H. ${ }^{4}$ )

hayo P. ${ }^{5}$ )

je woord

kom L. ${ }^{6}$ )

wij zingen-omdat

,wctap telemihe" een klein drinkschaaltje met water, dat de piiyai

drinkt bij zijn werk

\section{hëpuineleli}

§ 35. „Kupitakapüne” (,imak-pe-püin niet puisterig, monopsikala glad geworden"; kupita = puistje).

ayo Kuyuli mohkë

ayo Kuyuli kom

1) „Men ziet dit 's nachts; is een geest".

$\left.{ }^{2}\right)$ Onzeker of Awalimuit de naam van een geest is.

3) Mythische groote boom.

4) Idem, wellicht de Melkweg.

5) Een vogel.

6) Onzeker of Lopoko de naam van een geest is. 
ayo Kuleuulo aši

ayo ëwekena ma-topo

$\ddot{e} u$ monanimpo-kö

ayo iloptak

ayo pleumomane

ayo hale-k-lopa

ayo henoko yaši

ayo auenok-topöli

ayo müine Etakinu

ayo ilematopome

henoku yašin

ašitate ašin

enz. enz. ayo $\mathrm{K}$. tooverkracht

„, je nieuw begin-maker (?)

je toorn doe opheffen (,eyaptau

animpo-kö, animpo-kele")

ayo in mijn hart

, pijl oplichten (?)

, ga weg

, zend weg tooverkracht

,, je wegzender

; ... -pijl (,oude naam voor pijl")

, wegzender (,,als wind")

zend weg toovermacht

ga heen

$\S 36$. De kleine Tapau, wiens overleden vader medicijnman was, doet mij voor hoe deze deed; hij klapt in de handen, ziet naar boven en zegt:

puyai enoko man kapu-nak

medicijnman zenden hij doet

hemel-naar

püyai enokügwenok yeküpüip̈̈ idem

piai $n$-item medicijnman hij gaat

en dan komt de yolok als een kaikui (verscheurend dier).

Als iemand door yolok pleu is getroffen: müinmemale (in het medicijn huisje); bladeren hutje schudden; uitzuigen.

Medicijnspreuk over een wond, ëlik tëlemikai:

müya oli-yasi!

naar ginds kwaad-toovermacht!

müla uli-yase!

$\ddot{e}$-pata it $\ddot{e}-k$ !

(naar) je dorp ga!

$\S 37$. Er hebben op het dorp Boschnegers overnacht, waaronder een kind, dat erg ziek was. Als ze vertrokken zijn, zie ik aan den waterkant een der vrouwen van het dorp, zelf moeder van een jong kind, die met een mat zwaait over alle plekken waar de Boschnegers geweest zijn, zeggende: $u f$, itëkële (ga heen) $u$ pata- $k$ (naar je dorp); ze doet dit yemnë-pe-šike ziekte-vol-omdat en het heet yemnë towohakaimë.

$\S 38$. Tegen den regen zegt men: ufmai kopö (regen) ufmai kopapokililiši kapašimha (kapao ašimha, snel als een hert) of 
kapašima kopö, ašimhạk kapao, kapao ašimhạk); als de regenbui voorbij is, afdrijft, zegt men uf-kopö müya, weg regen naar ginds.

$\S 39$. In een huis staat op een plank in de schaduw een kalebas met aarde waarin een aroidee-plantje. De oude vrouw die in het huis woont, vertelt: mijn vader vertelde mij, dat men om de wilde Oayarikule-Indianen vredig te stemmen, den knol van zoo'n plant fijnwrijft en met water vermengt; men sprenkelt daarmede, of wrijft het op de eigen huid en zegt: kapalu matohinke; pleu matohinke; telei telei-ya (kapalu knots, pleu pijl). Men noemde die plant sëmuit ( $\$ 19$ hemüit; de $s$ en $h$ wissèlen in het Oayana) of kule-ka-top vredeswerktuig.

$\S 40$. Als er veel muggen zijn, maakt men een vuurtje en legt er bladeren van de kassave op, wier rook de muggen verdrijft; de jongen die dit doet, spreekt tot de mahak-umuit (muggen-geest), die ëlëšizükatip (miereneter-gelijkend) is : $y$-epinop-kë! yekelai hera wai wëtili; upak y-eliya, genees (help)! geven wil-niet ik zuigen, lang geleden (reeds) zuigen.

De wespen- of mierenproef.

$\S 41$. De ritus, door Crevaux en Coudreau ,maraké" genoemd, is voorgedaan door Kuyuli $(\S 7)$. Hij bestaat uit het ondergaan der steken van wespen of mieren, die in een bord van vlechtwerk zijn vastgeklemd, welk bord een bovenizinnelijk wezen ( $\S 11)$ voorstelt of vertegenwoordigt. Er zijn nog vele bijkomstigheden, en vermoedelijk heeft alles een beteekenis en doel.

De Oayana's noemen het $t$-epie- $m$ of $t$-epie- $m$ t-epu-he; het eerste woord is vermoedelijk verwant aan epiti, geneesmiddel, еріnори een geneesmiddel toepassen, het tweede $(e p u-r u)=$ steken door een insect. De Oayana's zeggen, dat ze hierdoor in zich krijgen datgene wat de Boschnegers obia noemen, dat is natuurkracht of magisch natuurwezen. Zonder deze behandeling zou hun huid slap blijven als bij een kind en men zou slaperig en loom blijven. Jongens worden er sterk door en goede jagers, meisjes ijverig en bekwame huisvrouwen.

Op den leeftijd van 6 à 12 jaar moet elk kind deze bewerking ondergaan, met de zeer groote mieren irak (Ponera clavata), of misschien met de iets kleinere en minder pijnlijke iyuk. Het geschiedt als openbare plechtigheid, meerdere kinderen bij dezelfde gelegenheid. Kinderen laat men ook zitten op een boomblad waarop een $i y u k$-mier is geplaatst. 
Nogmaals ondergaan de Oayana's de bewerking bij het volwassen worden. De meisjes worden onmiddellijk na de eerste menstruatie met irak-mieren behandeld, zonder uiterlijke plechtigheden en met een onversierd vierkant mierenbord; wanneer het alsdan afgeknipte haar weer is aangegroeid, mogen ze huwen (doch het komt voor, dat een meisje of jonge vrouw in de plaats hiervan deelneemt aan de eerstvolgende openbare wespenproef). Jongens ondergaan op den leeftijd van 14 à 18 jaar de wespenproef, meerdere bij eenzelfde feest. In het latere leven kan men zich nog een of meer keeren daaraan onderwerpen. Een man doet dat bijv., als hij te veel misschiet of als het wild te schuw is en laat dan vooral den linkerarm, die den boog houdt, steken; een vrouw deed het, omdat haar kind gestorven was en ze graag een ander kind wilde krijgen. Naarmate de betrokkene ouder is, wordt een kwader soort wespen gebruikt.

$\mathrm{Na}$ het steken wordt den patienten het haar kort afgeknipt en 5 tot 15 dagen (volgens verschillende opgaven) houden ze de hangmat, moeten zich onthouden van geslachtsgemeenschap en mogen slechts kleine stukjes kassavebrood en warm water nuttigen, en daarna is nog een tijd lang groot wild, vogels of visch, verboden spijs. Het zijn dezelfde maatregelen die bij de volken van Guyana worden toegepast bij menstruatie, voor en na de geboorte van een kind, na genezen van een ziekte, na een sterfgeval in de familie, na het dooden van een vijand en na de inwijding; dat is, vermoedelijk (vgl. perP 57, 72, pP 653,659 vlg.), bij omstandigheden waarin de mensch gemeenschap heeft met de geesten en uiterst voorzichtig moet zijn ze niet onrustig te maken, wijl daaruit ongewenschte werkingen zouden voortkomen.

Men mag wel aannemen, dat het steken ten doel heeft, de voor ijver, bekwaamheid en moed zoo nuttige krachten of deugden van mieren- of wespengeesten in den betrokkene te versterken (zie nog noot bij § 43). Bovendien stellen de mieren- of wespenborden meestal een diergeest voor, waarschijnlijk om ook dien geest aan te trekken, en zoo is het wellicht met alles wat als tooi of gereedschap wordt gebruikt bij. dezen ritus. Het lijkt mij, dat het bij de mieren- of wespenproef dus gaat om hetzelfde beginsel als bij eenvoudig gebruik van een tooverknol ( $(19)$ of bij de inwijding tot medicijnman. Het steken door mieren wordt ook bij andere volken met een dergelijk doel toegepast. Ook het moedig verdragen van erge pijn, heeft wellicht een gunstige werking.

$\S 42$. Voor de uiterlijke beschrijving der wespenproef moge ik verwijzen naar Crev 245-50, C 228-35, 544-56, 2G 17-21 met foto's, 
3G id., Ahl id. Hier volgt een kort overzicht, waarbij de beteekenis meer uitkomt.

De feesten en plechtigheden duren drie dagen. Het begint met inleidende dansen en het voltooien der voorbereidselen. Tevoren hadden de novieten het huis gebouwd, waarin zij verblijf zullen houden; de hangmatten die zij aldaar gebruiken, zijn nieuw. De danstooi, de fluiten enz. en de wespen- of mierenborden (voor elken noviet een) worden gereedgemaakt, en een etmaal vóór het steken worden de borden met levende wespen of mieren bezet; de dansvloer (welks geluid volgens Nimuendaju, $2 \mathrm{Far} 224$, de godheid waarschuwt, dat de dans aan den gang is), wordt gelegd; er worden gegiste dranken bereid.

De novieten zijn niet met roode Bixa-verf besmeerd, ook niet bij den dans; zij dragen aanvankelijk geen sieraden en hebben steeds een stuk pijlriet in de hand; bij hun dans dragen ze in de plaats daarvan, aan den arm gebonden, een pijl (2G Taf I, XIX) waarvan het vedereinde door een dradennet is omgeven, met boven een klein wiel, akalima-tawet $=$ spinneweb. Blijkbaar is het iets dergelijks als de staf dien de Kalienja-novieten dragen en waarmede deze ,het spinrag van zich afweren, anders zullen zij in de netten der boozen verstrikt raken." (pP 659).

Elke noviet heeft een beschermer; deze noemt den noviet $y$-eke $=$ onderhoorige of huisdier. Treedt de noviet uit de hut waar men hem aankleedt, of verwijdert hij zich van de dansplaats voor een natuurlijke behoefte, dan gaat de beschermer mede en houdt hem aan de hand vast en de beschermer of een ander stoot een langgerekten kreet uit, waarbij velen mederoepen. De novieten zwijgen steeds, mogen slechts fluisterend iets mededeelen.

Eerst vindt nu het $t$-epie-m apuru (apuru = afsluiting) plaats. De novieten worden getooid en dansen en mannen en jongens met palmbladeren, matten en derg. in de hand, dringen hen terug en sluiten ze ten slotte geheel in en de novieten worden uitgelachen en bespot. Misschien heeft dit een overeenkomstige bedoeling als het opsluiten in het inwijdingshuis bij Kalienja's en Arawakken.

's Avonds na donker begint de dans der novieten in vol ornaat; het komt erop aan, dat ze den dans den geheelen nacht onafgebroken volhouden; slechts een maal wordt hun wat water te drinken gegeven.

Met het aanbreken van den dag worden ze een voor een gestoken: een oude vrouw, of de hoofdman, drukt hun het wespenbord overal op de huid, waarbij de wespen steken (Ahl telde 360 wespen in één 
bord); weder komt het erop aan, niet te schreeuwen; flauwvallen komt echter voor. Daarna moeten de jongens onder den oksel door een balletje werpen of een pijltje schieten op een schijf en na den vastentijd moeten zij nog moeilijker schietproeven afleggen.

De tooi der novieten, waarvan, naar ik vermoed, elk onderdeel in verband staat met de geestenwereld, bestaat uit den grooten vederhoed $(\S 43)$, rugtooi van vederen, tallooze snoeren wit katoen, snoeren kralen, en ze dragen den danspijl en blazen op een versierde fluit waarin een klauw van het reuzengordeldier is verwerkt en aan de beenen dragen ze banden van rinkelende zaden. Het is bijzonder mooi.

Ahl heeft gezien hoe na afloop der wespenproef naast elke wespenmat haar evenbeeld is kassavebrood hing. Iets dergelijks vermeldt C 234, volgens wien dit brood instede van door vrouwen, door de novieten zelve is bereid, terwijl de figuren tot de volgende wespenproef blijven hangen.

\section{Z w eepdans.}

$\S$ 43. De zweepdans der Oayana's, beschreven Crev 258, 105, C 176 vlg., komt kennelijk overeen met den zweepdans van Makusi's en Taulipang's en dien van de Arawakken en eveneens met de gemaskerde dansen der Uaupesvolken (1Roth 138, 157, 2Roth 477, Martius I 632, 2Far 69, 1KG I 186 vlg., 310 vlg.). De danser stelt den geest Tamoktamok voor (die een tuna-kaikui is en iyum), wat ook de naam is van de groote blauwe Morpho-vlinders die in het duistere woud leven. Alles wijst erop, dat deze dansers de scharen van den oppersten woudgeest voorstellen en wellicht is het een ritus om de geesten die macht hebben over het wild en over het gewas, gunstig te stemmen ${ }^{1}$ ).

1) Vgl. met het woord Tamoktamok: Hianakoto (een karibenvolk in Columbia) Temekeme de stamheld, temanyike zweep, temekeme Morpho-vlinder; wellicht bevatten deze namen het karibische woord *tamo-ko oude man, grootvader. Evenwijdig hieraan beteekent het woord pia bij verschillende karibische volken „oud" ; Pia-ima is de naam van den woudgeest of van „Oudere broer" der tweelingmythe, die de eerste medicijnman was; mogelijk is hiermede het woord püyai, medicijnman (enz., zie § 10) verwant, misschien ook pia(na) zeer groote arend (Thrasaetus harpyia); 2KG I 80: een vlinder is de schaduw of geest van Piaima; vlinder Oayana pialor, Morpho-vlinder Tliometesem piaireimo metme. In de Ingariko-taal heet Piaima: ata tai (2KG II 80); Akawoi Piaima .... an Araidai or goblin of the woods (Brett 176); vermoedelijk is het Oayana-woord tai, zweep, hiermede verwant. Bij de Uaupes-Volken is de Morpho-vlinder heer der gemaskerde dansen (1KG II 181, 354). Met Piaima komt uvereen de woudgeest Kurupi der Kalienja's, Kurupira der Tupi's. 
Crev 259 zegt, dat het een doodenfeest is, doch het lijkt mij mogelijk dat dit een interpretatie is van de Boschnegers die hem begeleidden, welke zelve zulke doodenfeesten houden. Doch indien het juist is, dan behoeft het niet overeenigbaar met het hiervoren gezegde te zijn, zie $\S 8$ yolok en zie ook 2 Roth 471 , $1 \mathrm{KG}$ I 139). Ik heb den zweepdans niet bijgewoond.

De zweepdansers, die van andere dorpen komen, zijn in een mantel ( pono $=$ kleeding, nest) gehuld van reepen boomschors (okalat, naam van den betrokken boom, verm. Eschweilera), die in de lengterichting afwisselend geel gelaten en zwart geverfd zijn; deze mantel bedekt ook de oogen en reikt tot de knieën. Daarboven wordt op het hoofd de olok geplaatst, een hoog hoed-geraamte van vlechtwerk, bekleed met banden van vederen, elk van een bepaalde vogelsoort, de een boven den ander en bekroond door een stralenkrans van lange roode ara-vederen (gekleurde afbeeldingen en foto's $1 \mathrm{G}$ pl. III, 3Roth 74 en van Aparai's 2Far titelplaat en pl. XIX, SK 136, 162). Van een dergelijken aan de tapsem (§ 49) gehechten hoed, meldt C 552 „,'est le chapeau que porte Yolock quand on le rencontre dans la forêt". De figuur in mozaiek aan de voorziide van een der olok's werd uitgelegd als voorstellend den geest Meku'om. Toen ik op het dorp van den hoofdman-medicijnman Taponte een olok kocht, tuigde Taponte met een paar oudere mannen den olok op en verzocht mij daarbij wat sterke drank uit te deelen, ,want een olok is een groot iets; wordt geen drank geschonken dan moeten alle Oayana's sterven". Vgl. nog meP III 141 Kalienja regenboog $=$ de umalidi (vederkroon) van Yoleka, den Ewalu-mu (duisternis-geest).

In de hand dragen de dansers een stok met een vele meters lang, dik zweepkoord, welke zweep tai heet, of Tamok-tai.

De dansers verschijnen in het dorp, geheel gekostumeerd, zwijgen, volvoeren een voor een een rondgang, dansend, waarbij ze de zweep laten knallen. Dan treden de mannen van het dorp op, die in eenvoudig danskostuum zonder mantel, de zweepdansers omzwermen en „,bijen" voorstellen ${ }^{1}$ ). Bij de volgende dansen zijn die bijen de be-

1) Bij de Makusi's enz. zijn het „kolibries” die de zweepdansers omzwermen (2Roth 474 vlg., 2KG III 158). Het zou kunnen zijn, dat de kolibrie hier de ziel van een medicijnman of overleden medicijnman voorstelt (zie noot bij § 9) en dat ten tooneele wordt gevoerd, hoe de Indiaan de medicijngeheimen aan de naturgeesten ontfutselt. In een Tembe-mythe steken kolibries den demon met de lange haren (2Nim 286). In de Arawaksche mythe van Makanahoro, den knappen medicijnman, welke mythe, naar een Arawak mij mededeelde, het verhaal van een inwijding is, wordt de opperste der demonen door de steken van 
schermers van de zweepdansers, op dezelfde wijze als de novieten der wespenproef een beschermer hebben. Het feest duurt meerdere dagen. Mij werd verteld van een dans okomo-me, wespendans, waarbij men de okalat draagt en geen fluit speelt, alleen zingt.

De behandeling van een zieke, beschreven $1 \mathrm{G}$ 26-7 en $1 \mathrm{Fr}$ lijkt mij eenzelfde soort ritus, doch vereenvoudigd.

\section{Andere dansen; muziek.}

$\S$ 44. Er zijn nog vele andere dansen, en men behoeft er niet aan te twijfelen, dat deze, althans oorspronkelijk, met de geestenwereld verband houden. C 176 vernam omtrent den oorsprong van den tuledans de volgende mythe: „Op een dorp waren alle mannen afwezig en slechts een vrouw was gebleven. Tegen den avond zag zij uit de beek onbekende Indianen te voorschijn komen, die veel kaširi dronken en den geheelen nacht een haar onbekende dans uitvoerden. Bij het aanbreken van den dag verdwenen ze weder in het ondiepe water van de beek. De vrouw heeft aan de mannen van het dorp dien dans onderwezen en het kostuum dat erbij behoort en sedert danst men overal bij de Oayana's de tule”. Vgl. 2KG II 120-3, 4Nim 89, 1Str.

De volgende namen der fluitmelodiën waarop men danst (of namen van fluiten) werden mij opgegeven: ëlëpu of elepu, kalau, kënkëlu, kolokowe, pililiwa, talihana, tayaya, tönekale, tule, waitakala (op een fluit met zeer zwaren toon).

De fluiten zijn van bamboe van het klarinet-type; ze worden den dag vóór het feest vervaardigd en op elkaar afgestemd. Men bezigt ook dwarsfluiten. De 3 tot 6 fluitspelers zitten op bankjes en vormen een orkest (vgl. Iz 397 vlg.); bij een dans dien ik bijwoonde, speelde telkens een een soort solo, waarop dan het geheele orkest antwoordde; bovendien blazen de dansers zelf op fluiten.

Voor zoover mij bekend, bestaan deze dansen uit een nogal plechtstatigen rondgang (Crev 296, C 187, 2G 17, Aparai SK 136) waarbij

mieren genoodzaakt zijn gelaat te onthullen; in de overeenkomstige Taulipangmythe (2KG II 90) zijn het wespen. In een Warau-mythe (1Roth 335) sluiten de tabaksgeesten vriendschap met wespen; wie een goed medicijnman wil zijn, moet de namen der geesten vinden, van welker macht hij zich zal bedienen In de mythe uit Guatemala van den tocht der goddelijke broeders naar de onderwereld (welke mythe ik houd voor het verhaal of voorbeeld van een inwijding), komt ook het steken door wespen voor (Popol Vuh, $\mathrm{Kr}$ 177) en eveneens in een gezang in Brazilië (1BR 308, 2BR II 202). In die mythe uit Guatemala worden de vorsten der onderwereld door de steken ertoe gebracht elkaars namen te verraden. 
soms (of meestal ?) dieren worden nagebootst (vgl. Sp 257, RB1 62, 2Roth 454, 1Str 800 vlg.); C 174, 185, 187 noemt de akomö (wesp), asisala, mamsali (loopvogel Psophia), 2G 20 akuli-putpö (landschildpad),, 2G 20 (met foto), Ahl ka t-utat-se (de visch is verdwaald), wat echter meer spel is dan dans (iets dergelijks 1KG II 167).

Ik hoorde een danslied waarbij maipuri (de tapir) en een waarbij alagua (de fazant, Ortalida Motmot) wordt bezongen. Toen er een dag gegiste dranken bereid waren, trippelden een paar kleine meisjes, een weinig dronken, waarbij ze het volgende danslied zongen op de hakola (of šakola, d.i. een bepaald soort drank):

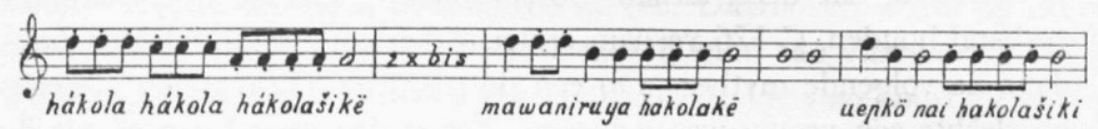

afgewisseld met: hákola hákola hákola hapalapkë

mawaniruya timatai-kë

hákola hákola hákola-sikë enz.

Een opgestopte zwalüw, die aan den gordel werd gedragen, zong men toe met šimišimi peinomó (zwaluw kinderen) Mapayuli (de naam van het diertje).

Voorts is er een dans, of zijn er meerdere dansen, waarbij de tapsem of tamoyetpe, een aan een plankje bevestigde olok wordt gedragen (2G fig. 13a, 13b, 1G 11, C 552). Zie hierover $\$ 49$.

$\S 45$. Hier volgt nog een opsomming van de mij bekende muziekinstrumenten der Oayana's :

1. dansvloer (plank over een holte; 2G Taf XIX fig. 2, 4, XX fig. 4, Iz 11);

2. beenband waaraan rinkels van Thevetia-zaden (1G pl. I fig. 24 , Iz 91);

3. schildpadschild, waarvan uiteinde borstschild besmeerd met balata-pek; door daarover met de hand te strijken, geeft het een toon af (1G pl. VII fig. 14, Versteeg 327, Iz 161);

4. bromslinger (bullroarer, Schwirrholz) van een kalebasje met gat, dat aan een touw wordt rondgeslingerd en dan een zoemtoon afgeeft (Iz 208), yolok eu, geest-gefluit; zie nog § 47.

5. een bromtol, zijnde een dergelijk kalebasje waardoor een stukje pijlriet als spil is gestoken, verm. kinderspeelgoed;

6. een hoorntje van een opgerold blad van den palm Astrocarium Paramaca, verm. kinderspeelgoed, of om wild te lokken ( $\mathrm{Iz} 253$ ?); 
7. een lange dunne met de neus bespeelde dwarsfluit van bamboe (1G pl. VII fig. 11, SK 200, Iz 301 ?);

8. bamboe klarinetfluiten ( $\mathrm{Iz} 257$ ) groote en kleine (1G pl. VII fig. 9) voor den dans; een stel van een enkele fluit, umuit geheeten en een dubbele, akina geheeten, had de volgende tonen: de enkele (1), de dubbele (2);

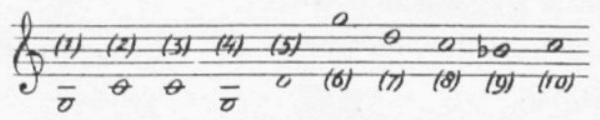

9. gewone bamboe dwarsfluit (1G pl. VII fig. 12, Iz 276); een stel van drie fluiten had de volgende tonen: de langste, tẹkkalu (3), de middelste umuit (4), de kortste woli (vrouw ?) (5);

10. kleine eind-fluit van hertenbeen die men voor pleizier bespeelt (1G pl. VII fig. $10, \mathrm{Iz} 308,318$ );

11. dansfluit met gordeldierklauw (2G Taf I fig. 2, 2a; het geluid wordt niet, als Iz 344, voortgebracht door den klauw, doch door het riet);

12. pansfluit (1G pl. VII fig. 13, Iz 378), wordt door den danser bespeeld tegelijk met het schildpadschild, no. 3 .

Een pansfluitje had de volgende tonen: $i$-mumku (het kind, de pink) (6), vervolgens (7), (8), (9) en umuit (vader, basis, duim) (10).

Een rammelaar wordt door de Oayana's niet gebruikt. De fluiten zag ik nooit anders dan door mannen bespelen.

Zoetklinkend fluitspel van een man om een vrouw aan te trekken (waarbij hij ook een toovermiddel gebruikt, § 19g): tinele ku mökënё = spoedig kom.

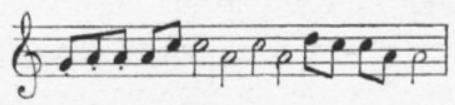

Zoetklinkend fluitspel om een kind te sussen.

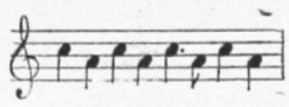

\section{Geboorte en dood.}

$\S 46$. Een meisje, dat de eerste menstruatie krijgt, moet in de hut blijven, en als het huis een zolder heeft, op dien zolder. Ze mag alleen kassave met pepersaus eten; ze mag niet spreken en niet naar den waterkant gaan. Daarna ondergaat het meisje de mierenproef (§ 41); akinama mule, akomne wahluma, tevoren was ze kind, nu is ze vol- 
wassen meisje. Bij het intreden der menstruatie is haar haar afgeknipt. Als dit weer is aangegroeid, mag ze geslachtsgemeenschap met een echtgenoot hebben (het leek mij, dat men niet wacht, tot het haar weer geheel lang is geworden, zie foto 11 Uluwa).

De vrouw die menstrueert, behoeft niet in een afzonderlijke hut te verblijven. Het bloed vangt men op door een stijf aangehaalde oude kamisa (lendendoek) die later gewasschen wordt.

$\mathrm{Na}$ een bevalling houdt een vrouw geruimen tijd de hangmat, de man (couvade) slechts 3 dagen.

Een man heeft een of twee vrouwen, enkele malen drie of vier. Er zijn nogal weduwen zonder man, die bij familie inwonen, en nogal ongetrouwde mannen. Deze hebben wel heimelijk gemeenschap met getrouwde vrouwen, en als de echtgenoot dat bemerkt, ranselt hij den schuldige. Naar het schijnt is er veel gemeenschap buiten het huwelijk; zie ook C 127 vlg., Gilij II 126. Men zeide mij, dat Oayanavrouwen zich niet aan Boschnegers geven. De Granman der Bonni's, Avinsai (door de Oayana's Kwassi genoemd) is een paar malen met een Oayana-vrouw gehuwd geweest, doch de Oayana's vonden dat niet prettig.

Men is dol op de eigen kinderen. Weduwen en weezen worden door de familie verzorgd. Doch C 216 zegt ,Qui n'a ni père ni mère chez eux ni oncle ni tante, peut avoir des chances d'être abandonné de tous". Op Pikien Kondre bij Drietabbetje aan de Tapanahoni zag W. F. van Lier een Indiaansch meisje, Totoli, dat leefde bij de DjoekaBoschnegers als een hunner en daar ook huwde, doch kinderloos overleed. De Djoeka's vertelden (en mij is dat bevestigd), dat omstreeks 1903 twee hunner op een Oayana-dorp kwamen, toen men op het punt stond dat meisje, dat toen omstreeks 6 jaar telde, op den brandstapel te werpen, daar de moeder was gestorven en het kind geen familie meer had (iets dergelijks: 1Roth 157).

$\S 47$. Twee sterfgevallen heb ik medegemaakt, de eerste keer van Mayawah, die weduwe was, de tweede maal van Kenelupke (zie foto 2 ), jongste der beide vrouwen van Nameyai.

Terwijl de zieke nog leefde, begonnen de naaste verwanten reeds met den klaagzang. Toen de dood intrad, begon de geheele bevolking van het dorp door elkaar te klaagzingen. Onmiddellijk na den dood, bracht het naaste mannelijk familielid (bij Kenelupke haar echtgenoot) alle trommels, kommen, spingerei enz. van de overledene naar de rivier, sloeg alles met een kapmes stuk en wierp het midden in den stroom. Vervolgens werden ook, onder veel tranen en klagen, 


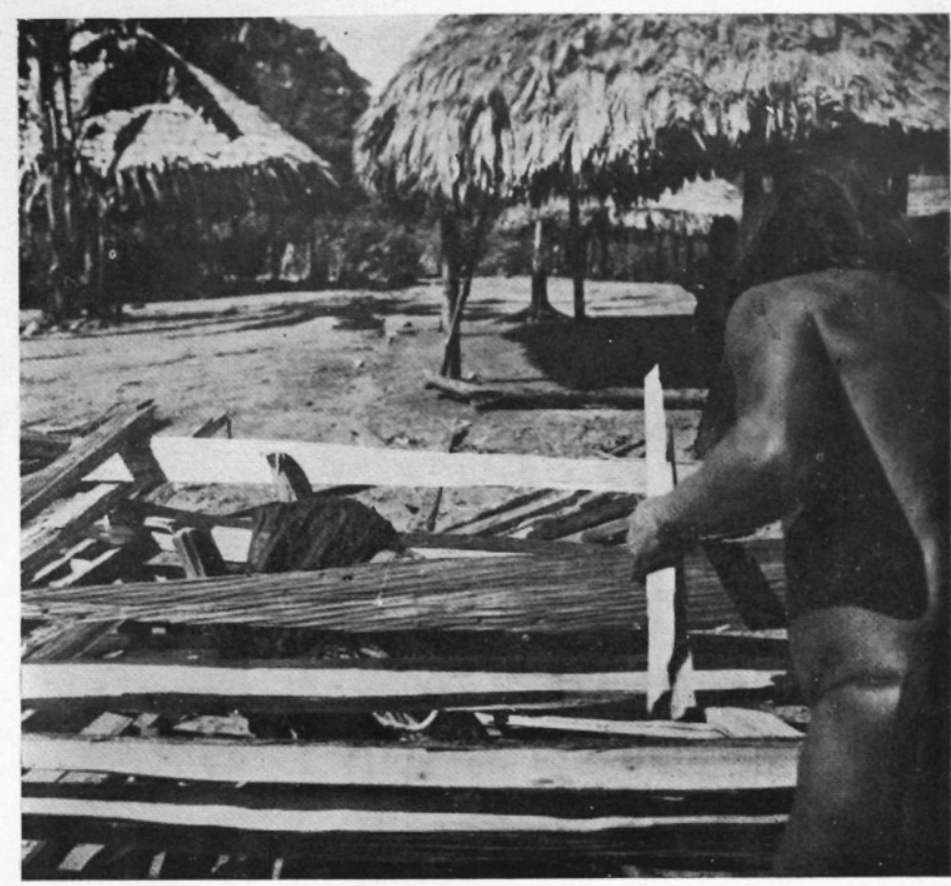

Foto 7. Oayana-dorp Taponte 25 Juli 1937; verbranding van het lijk der vrouw Mayawah 25 Juli 1937; de brandstapel wordt opgebouwd om het lijk, getooid met alle sieraden en een hoofddoek.

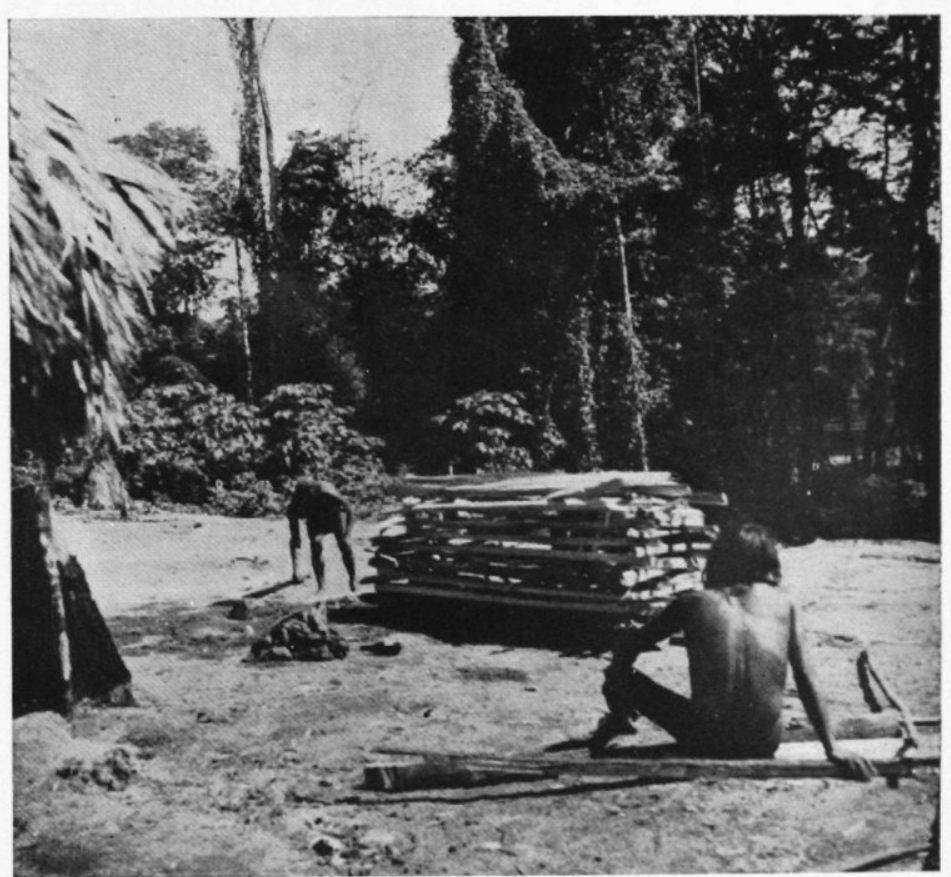

Foto 8. Vervolg lijkverbranding; de brandstapel is aan het voeteinde aangestoken. 


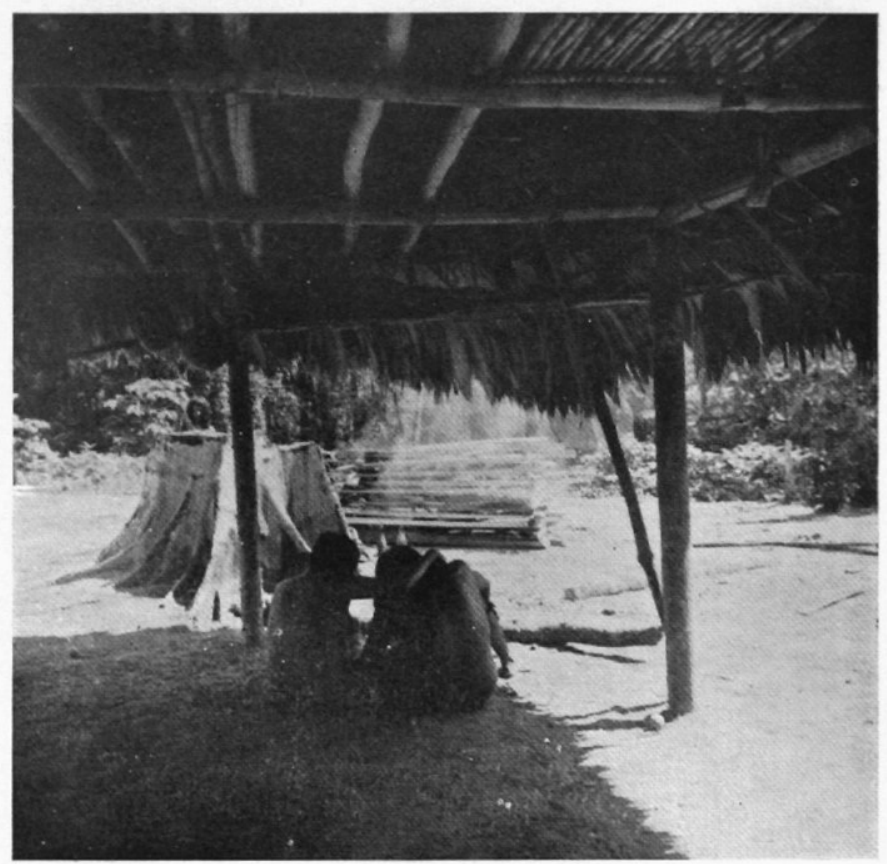

Foto 9. Vervolg lijkverbranding; Teponaike, neef der overledene (rechts), en de buurvrouw Aliana treurend in huis; buiten de brandstapel.

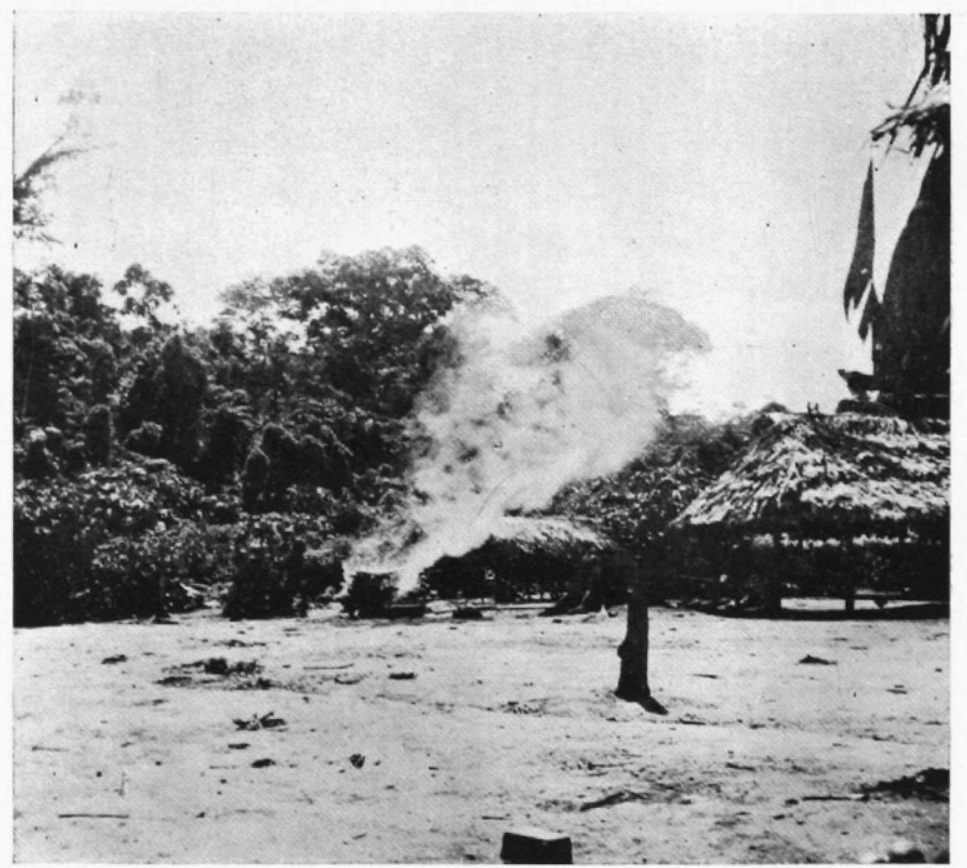

Foto 10. Vervolg lijkverbranding. 
de aarden potten van de overledene en haar waterkalebassen, stukgeslagen. De eigendommen worden vernietigd, opdat de yolok niet terugkome. Een tijd na het overlijden der weduwe, zag ik in haar hutje op de wijze. van een hangmat, een sliert tak met blad van de zoete patat hangen; dat was, opdat als de yolok van haar vroegeren echtgenoot (een medicijnman) er zou komen, hij gerust zou wezen ${ }^{1}$ ). Een man, die bij de verbranding geholpen had, kreeg enkele dagen daarna, pijn in de borst; het was ,geestenpijl” en hij meende, dat het wellicht veroorzaakt was door dien echtgenoot, die niet goedvond, dat zijn weduwe verbrand was. Een paar maanden later kwam die yolok (,zijn gelaat is als de mantel van reepen boomschors van den zweepdanser"), komende van dat hutje, de bewoners van een ander huis 's nachts lastig vallen ( $\$ 20$ e)) ; ook zwierven er jaguars rond; de honden hadden. aangeslagen ${ }^{2}$ ).

[Ahl vernam, dat toen onlangs een man was gestorven, onmiddellijk iemand door het dorp liep, een kort stuk hout als bromhout ( $\$ 45$ ) aan een koord rondslingerend, ter verdrijving van den yolok.]

Er zijn families die hun dooden begraven; andere families verbranden hun dooden; doch een medicijnman verbrandt men niet. [Crev 298 vernam : de ziel van den medicijnman blijft aan het lichaam gehecht in den kuil en daar komen dieren en menschen hem raadplegen $\left.{ }^{3}\right)$. Ahl vernam: iemand die een natuurlijken dood sterft, of die een zeer deugdzaam mensch was, begraaft men. Men verbrandt degenen die door invloed van en boozen geest zijn gestorven, waartoe gerekend geestenpijl ( $\$ 18$ ), val uit een boom, plotselinge dood; echter niet: slangebeet, verdrinken, sleepende ziekte, verval van krachten door ouderdom].

Voor het begraven wordt een ruime kuil gedolven en van binnen bekleed; het lijk wordt er achterover leunend (als bij de crematie) in geplaatst, met het gezicht naar het Westen; de kuil, die als een soort grafkelder is, wordt van boven gesloten door een laag stokken waarover boombast en vervolgens aarde. Men begraaft in het huis van den overledene, in een huis in een verlaten dorp of in het bosch; men cremeert op het dorpsplein of in het bosch. Het lijk van een hoofdman

1) Doch vgl. 1Roth 179: Volgens de Kalienja's hebben boschgeesten een afkeer van zoete patatten.

2) Misschien was die yolok een jaguargeest, Crev 298 en het geloof in Guyana, dat een medicijnman zich in een jaguar kan veranderen, 1KG II 155, 2KG III 200, 381, 1Roth 354 vlg., 341, Metr 84.

3) De Indianen van Vuurland zeggen, dat het lichaam van den medicijnman anders is dan van andere menschen. Uitvoerig bij Gusinde I 741, II 1390. 
of medicijnman wordt ook wel in zijn hangmat in een huis van het dorp geplaatst, en daarna wordt het dorp verlaten.

$\S 48$. De vrouwen die tijdens mijn verblijf bij Taponte stierven, zijn beide verbrand (zie voor de crematie van Mayawah, foto's 7-10). Kort na het overlijden bracht men op het dorpsplein stukken van bepaalde soorten hout, maakte daarvan een vloertje met twee schuin in den grond gestoken stukken hout als ruggesteun. Het lijk werd in zittende houding, leunende tegen die schuine houten, op dezen onderbouw geplaatst, de voeten naar het Westen; vervolgens bouwde men daarom als het ware een kooi van brandhout. Het lijk was getooid met kralenschortje en alle verdere sieraden van de overledene, hoewel dit, met de andere vernietigde eigendommen, een vrij groote waarde vertegenwoordigde.

Aan het voeteneinde werd er de brand in gestoken, enkele uren slechts na het overlijden. Hangmat en enkele nog vergeten voorwerpen werden mede in het vuur geworpen. Na een paar uur was het hout opgebrand en van het lijk was nog slechts een klomp vleesch van romp en ingewand over. Er werd nieuw hout bijgeplaatst en nog eenige uren later was er alleen nog maar asch met splinters verkalkt gebeente over. Den volgenden dag werd de asch in een huis begraven.

Tijdens de crematie was er algemeen klaaggezang. Na afloop knipten de naaste bloedverwanten hun hoofdhaar, wenkbrauwen en oogharen kaal af en ook hun katoenen beenbanden sneden ze af en dat alles werd in de rivier geworpen.

Bij de tweede crematie deed men ,toimai”, verjagen van den yolok, die, als hij bleef, nog meerdere menschen zou doen sterven. Men legde een mat, een kassavepers, een kalebas op den brandstapel en stak er een versch beschilderde roerspaan in; daarna wierp men eenige malen een peperdroogmat (vgl. $\S 20 \mathrm{~g})$ ) over den brandstapel en vervolgens schoot men op het reeds deels verbrande lijk met pijlen, waaraan als punt een versch beentje van een mamhali (loopvogel Psophia), en op verzoek loste ik bij het begin eenige geweerschoten over den brandstapel en later twee schoten in den nog niet verbranden vleeschklomp. Een aanwezige ,zag” den yolok weggaan en iets later kwam het bericht, dat Taponte, die wegens ziekte in zijn huis bleef, den yolok met verbrijzelde kaak en vernield onderlijf had zien heengaan. Niettemin werd ik in den namiddag geroepen, omdat Taponte een yolok (of het dezelfde of een andere was, weet ik niet) gezien en gehoord had (riep $\ddot{e} u h, \ddot{e} h, \ddot{e} h$ ) in het kreupelhout naast het dorp, en men wilde dat ik erop zou schieten. (Iets soortgelijks heeft 
Nimuendaju meegemaakt bij Guarani’s, 1Nim 312-4).

[Ahl vernam: $\mathrm{Bij}$ het verbranden werpt men alle beenderen die men maar vindt in den omtrek, mede op den brandstapel. Bij een man bindt men met het koord van diens boog den keel dicht en bindt ook de polsen aan elkaar en eveneens de voeten; hierdoor wordt de yolok die zich in het lijf bevindt, belet te ontsnappen. Men breekt zijn boog en steekt een stuk daarvan in het lijk, tusschen de ribben, als de yolok hem in het bovenlijf had getroffen, in het onderlijf, als de yolok hem in het onderlijf had getroffen. De rook zal den brandenden boog heendrijven naar den medicijnman die den yolok had gezonden en den moordenaar dooden. Om dit laatste te bevorderen worden ook wel de beide pinken van den doode afgesneden. - Als iemand in het bosch verbrand wordt, dan wordt door, of onder leiding van, een medicijnman, het hart uit het lijf gesneden en in een pot gedaan met krapa-olie, mais, spaansche peper en petp $\ddot{e}$ (een struikje, dient ook bij de bereiding van urali-pijlgift). Na een tijd begint het hart te pruttelen; dat is de yolok die spreekt. Wanneer het goed kookt, doet de yolok den pot barsten en op hetzelfde oogenblik wordt de moordenaar-medicijnman aangegrepen door razernij. Hij grijpt het vuur en eet het, bijt zijn eigen vingers af, enz., en weldra sterft hij (vgl. 2Far 75 ). Van een in het bosch verbrande wordt de asch met stukjes been ter plaatse begraven.]

$\S 49$. Enkele generaties geleden, kwam het voor, dat als een man oud was (,tamuši-zvet”; misschien werd bedoeld de hoofdman Ouèt, vermeld door C 237, 565), hij verzocht gedood te worden (vgl. nog $3 \mathrm{KG} 231$ ). Men doodde hem met een knots, sneed al het vleesch van het geraamte en at het vleesch. Het geraamte werd bij de knieën afgebroken; men bevestigde het op hout en danst ermede (de schedel werd afgesneden en in een mandje bewaard). Datgene waarmede werd gedanst, heette tamo-yẹtpe (grootvader-gebeente) (vgl. Metr 92, 240, 7Roth 158-9, 1Strad 812-3, Martius I 485). Tegenwoordig danst men nog met een plankje waaraan houtjes beyestigd zijn, die de beenderen voorstellen; dat er een olok aan bevestigd wordt, is iets van later tijd (zie § 44).

Van een neger-creool die lang bij Oayana's vertoefd had, vernam $\mathrm{ik}$, dat men met tamoyetpe ook aanduidt een geneesmiddel dat gedronken wordt en waarin gemengd zijn de asch der beenderen van een doode, de verbrande kop van een gier, en nog meer.

$\S 50$. De ziel (amolimpö, akualimpö) gaat terstond na den dood op weg naar Kuyuli en bereikt binnen enkele dagen haar bestemming. 
Op weg ontmoet ze dePëlë-yum (paddengeest, § 7) en ze moet over een smal bruggetje over een groot water, waarin het monster Kënekë zwemt, dat is als een pëne (roofvisch Pigocentrus). Wie slecht is, in het bijzonder een vrouw die haar ongeboren kind heeft gedood, of misschien wie alleen maar schrikt, valt in het water en wordt verslonden $^{1}$ ). Is het lijk begraven, dan krijgt de ziel reeds den eersten dag voedsel van Kuyuli, is het lijk verbrand, dan pas den zesden dag en daarna wascht de ziel rook, asch en stank van zich af. De ziel komt op haar weg naar Kuyuli ook aan een zeer grooten boom Alaula pepta; op een grooten boom Kapitë-ime-po is er een kaikui, de groote roofvogel Tiutiu of Tïetüe die den weg afsluit (vgl. Gilij III 13 Tighitighi en 1Roth 161). Ze komt ten slotte aan in het door Kuyuli voor haar gesticht dorp. Er zijn daar dorpen voor Oayana's, voor Blanken en voor Negers. Kuyuli woont op een groote, mooie rots, met vele zeer groote wespen. Hij is als een Oayana die een apomali (hoofdkrans van roode, gele en zwarte veertjes, IG pl. II 6) draagt; de zon is zijn vader.

[Ahl vernam: De doode neemt de slagvederen van den koningsgier ( $(9)$ en een geest voert hem omhoog naar de godheid; ook degenen dïe siechíc waren. Crev 298 vernam: đe goeden stijgen zeer hoog boven de wolken en leven daar in vreugde, de slechten blijven onder de wolken.]

$\S 51$. Na een sterfgeval wordt door de nabestaanden nog dagelijks de klaagzang gezongen, wat echter gaandeweg minder wordt; toch werd in het dorp waar ik vertoefde, door Kulewa, weduwe van den een paar jaar geleden gestorven Amentano, nog herhaaldelijk en langdurig klaaggezongen, en eveneens door Aliana, zuster van Amentano. De aanleiding om 's nachts den klaagzang in te zetten, is, dat de doode in den droom verschenen is.

Klaagzang van Kulewa :

emühenei -mnerumö (helaas mijn gewezen echtgenoot) emiihene i-mnerume-hene

of :

emühenkia i-mnerum henma kinaha (ik verlang naar je, mijn echtgenoot, helaas)

mökelenekë, ehewahenekë (kom, kom bij mij) möhkele (kom)

Men doet geheele verhalen in den klaagzang, waarbij men de deug-

1) Een dergelijk geloof is algemeen in Guyana, en komt ook in Europa voor. 
den van $\operatorname{de}(\mathrm{n})$ overledene bezingt, of misschien allerlei herinneringen ophaalt.

Een reisgezelschap waarvan op de reis een der leden gestorven is en elders begraven of verbrand, komt in de boot klaagzingend op zijn dorp terug. Menschen die op een dorp komen, waar sedert hun vorig bezoek iemand is overleden, gaan naar de familie en zitten met deze, waarbij men elkaar omarmd houdt, een tijd te klaagzingen ${ }^{1}$ ).

Klaagzang van Kulewa en Alina om beurten

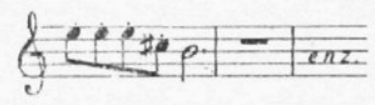

Klaagzang van Nameyai na den dood van zijn jongste vrouw Kenelupke

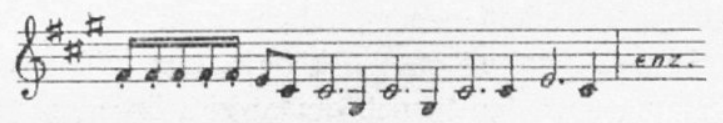

Samenleving.

§ 52. De samenleving berust op het gezinsverband naar grondslagen van matriarchaat. De man is tamuši (oude, hoofdman), zijn schoonzoons en wie zich verder bij hem aangesloten hebben, zijn pöito (jongen, vazal) en elk dezer heeft zijn gezin bij zich en soms weder eigen pöito's. Zoo'n gemeenschap, tellende 10 tot 50 personen, heeft een eigen dorp met 1 tot 4 gezinshuizen en enkele hutten waar de vrouwen voedsel bereiden.

De dorpsgemeenschappen van eenzelfde rivier rekenen zich iets nauwer met elkaar verbonden dan met die van andere rivieren, waarbij echter ook bloedverwantschap een rol speelt; aan de Litani gold in 1937 Taponte eenigszins als opperste hoofdman. Overigens berust de samenhang van den geheelen stam op gemeenschappelijke traditie, gebruiken en taal en blijft in stand door bezoeken en huwelijken.

De hoofdman laat zijn vazallen het zware werk voor hem doen, doch hij regelt de werkzaamheden, helpt een handje mede, en Taponte, die medicijnman was, ging geregeld rond bij de zieken van zijn dorp en was als een vader voor zijn onderhoorigen. Overigens heerscht er de grootste denkbare persoonlijke vrijheid. Men neemt nauwkeurig de hoffelijkheidsvormen in acht.

Het ambt van tamuši is erfelijk, doch men let er ook op, of de

1) Zou iets dergelijks de oorsprong kunnen zijn van den tranengroet bij de Tupi's en anderen (Metr 180)? 
candidaat een vast karakter heeft en daarbij bezadigd en vriendelijk is. Waarschijnlijk wordt de opvolging min of meer tevoren geregeld en hebben de oude hoofdlieden daarin veel te zeggen. Maar ieder is vrij om een nieuwen tamuši al dan niet te accepteeren en als een tamuši overlijdt, ontstaan er dikwijls hergroepeeringen.

Tijdens mijn verblijf bij Taponte, stierf de hoofdman Lapo (Laveaux, een zoon van Panapi $\dagger \pm 1930$ ). Zijn onderhoorigen stichtten onder Yanamale een nieuw dorp, doch zijn broeder Sampati (Jean Baptiste) of Wempi besloot zich bij Taponte te voegen. Op een namiddag kwam hij met gezin per boot, klaagzingend, aan en begaf zich daarop, steeds klaagzingend, alleen naar het dorp, in de hand een stuk pijlriet houdend, welks boveneinde een roode ara-veder droeg. De geheele bevolking zette nu den klaagzang in voor Lapo, en dat ging vrijwel onafgebroken den ganschen nacht door. Toen het dag was, sprak Sampati, zittend op een bankje, met luide stem, in korte rhytmische zinnen met den hemel, omdat zijn broer dood was. Men noemde dit tewetašikai, wat wellicht vertaald mag worden met ,zich zuiveren van toorn". Voor zoover ik het kon verstaan, gaf hij een uiteenzetting van wat er alzoo geschied was en hoe hij met Taponte had gesproken en zich nu bij dezen voegde. Soort biecht?

Taponte zeide mij een keer ,ik wil sterven”. Die wensch is niet lang na mijn vertrek in vervulling gegaan. Het lijk is in zijn huis begraven en zijn onderhorigen hebben zich in twee groepen gesplitst, die elk een nieuw dorp hebben gesticht. In 2 jaar tijds 6 sterfgevallen op de 50 menschen.

Ik moge, ter bekorting, voor het overige verwijzen naar mijn opstel 9G.

$\S 53$. De vrouw noemt haar echtgenoot $i$-mne-rum, mijns kinds vader, de schoonouders hun schoonzoon $i$-pal-um, mijns kleinkinds vader, hun schoondochter $i$-pa-he, mijns kleinkinds moeder. Alle Oayana's hebben een eigennaam. Veelal wordt die aldus gegeven: een meisje krijgt van de grootmoeder den naam van grootmoeders moeder, een jongen van den grootvader, den naam van grootvaders vader. Zoo had Tuanke (C 103 vlg.) een zoon Paike (C 106), deze een dochter Ëki en haar zoon heet weder Tuanke. Eveneens is er een jongetje dat Yakuman heet naar den hoofdman uit den tijd van Crevaux en Coudreau (Crev 652, C 235, 2G 31).

Ook de honden hebben een eigen naam: Alukole (luiaard), Seki, Maulu (katoen).

En de dorpen hebben een eigen naam, in 1937 Taponte dorp 


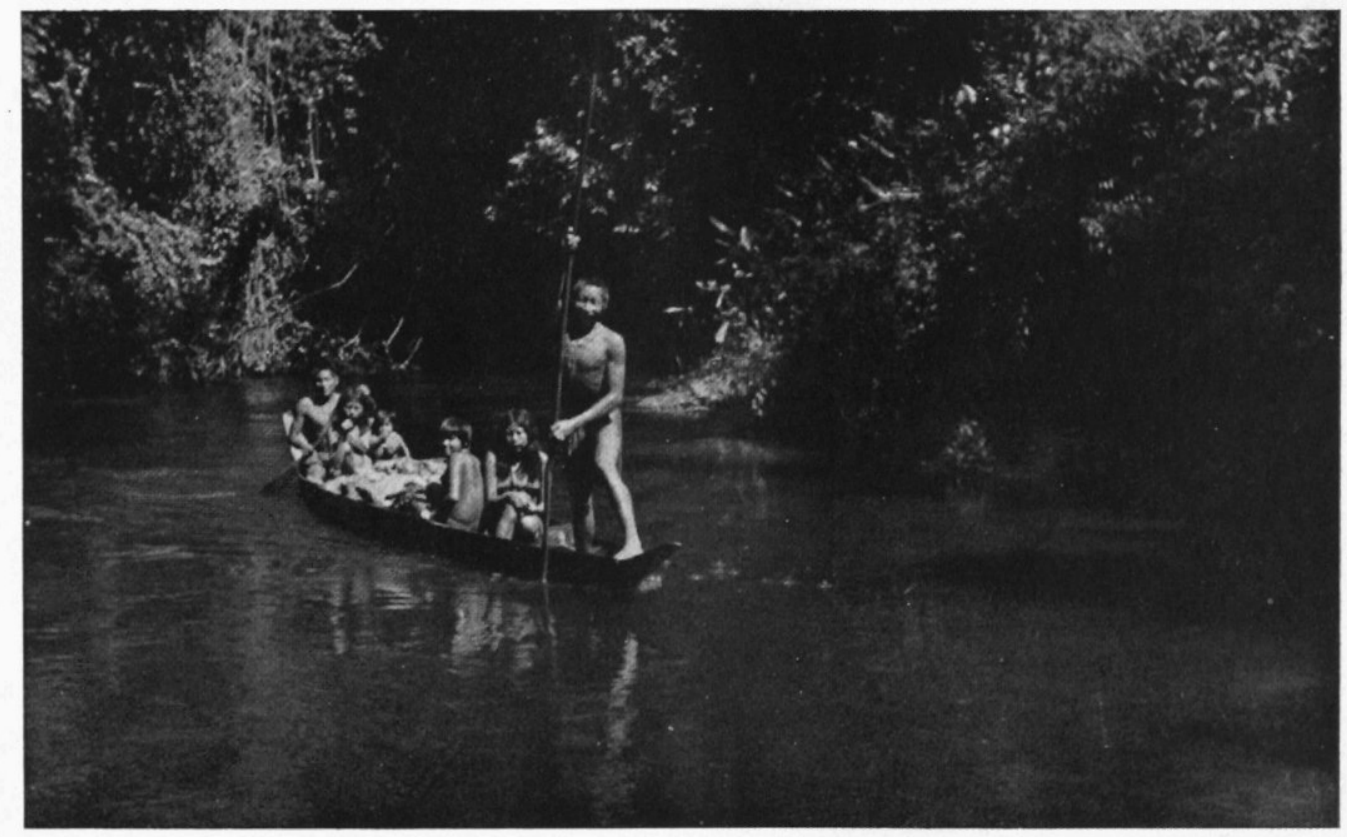

Foto 11. Oayana-boot in de Waroemapan. Sampati (achterin) met zijn twee vrouwen en kindje, Teponaike (voorop) met zijn schoonzusje Kuluwa (middenin). Foto grensexpeditie 1937. 
Kumaka-pan (Ceyba-boom plaats), Malataiwa Doisine, Lapo Autëmanu, Wapurumuit Suye akulika-top (ketel-barst-plaats).

Alle rivieren en kreeken hebben een naam, alle stroomversnellingen en vallen, en de bergtoppen. Tegenwoordig kennen enkele Oayana's onzen naam voor het grensgebergte: Toemoekhoemak, doch dit hebben zij kennelijk van de Franschen geleerd $^{1}$ ).

\section{A angehaalde werken.}

(* bevat oorspronkelijke gegevens over Oayana's; ** idem over Aparai's).

afkorting

eAhl W. Ahlbrinck, Encyclopaedie der Karaïben, Verh. Kon. Ak. Wet. Lett. XXVII 1, Amsterdam 1931.

Ahl id. Reisbeschrijving 1938, Ms.

1BR J. Barboza Rodrigues, Poranduba Amazonense, Ann. Bibl. Nac. XIV, Rio de Janeiro 1890.

2BR id., O Muyrakyta, Rio de Janeiro 1899.

B1 M. Ruiz Blanco, Conversion de Piritu, Madrid 1892 (1e uitg. 1690).

W. H. Brett, Legends and Myths of the aboriginal Indians of British Guiana, London.

C *H. Coudreau, Chez nos Indiens, Paris 1893.

Crev ***J. Crevaux, Voyages dans l'Amérique du Sud, Paris 1883.

1Far W. C. Farabee, The central Arawaks, Philadelphia 1918.

2Far **id., The central Caribs, Philadelphia 1924.

1Fr *A. Franssen Herschee, Verslag van de Gonini-Expeditie.

T. Kon. Ned. Aard. Gen., Leiden 1905.

2Fr *id., Verslag der Tapanahoni-Expeditie, id. 1905.

Frontières entre le Brésil et la Guyane française. Second mémoire présenté par les Etats-Unis du Brésil.

F. S. Gilij, Saggio di Storia Americana, Roma 1781-2.

- J. Gillin, The Barama river Caribs of British Guiana, Papers Peabody Museum XIV 2, Cambridge, Mass. 1936.

- D. C. Geijskes, Aanteekeningen reis 1939, Ms.

$1 \mathrm{G} \quad *$ C. H. de Goeje, Bijdrage tot de Ethnographie der Surinaamsche Indianen, Int. Archiv f. Ethn. XVII Suppl., Leiden 1906.

$2 \mathrm{G}$ *id., Beiträge zur Völkerkunde von Surinam, Id. XIX, 1908.

3G *id., Verslag der Toemoekhoemak-expeditie, T. Kon. Ned. Aardr. Gen., Leiden 1908.

4G id., Das Kariri, Verh. XXIV Int. Amer. Kongr. Hamburg 1930 en J. Soc. Amér., Paris 1932.

1) „Toemoekhoemak" is stellig niet een naam die door ter plaatse wonende inboorlingen is gegeven; zie Marcel en 6G 77. 
5G id., Oudheden uit Suriname, op zoek naar de Amazonen. De West-Ind. Gids XIII, 's-Gravenhage 1932.

6G id., Suriname ontdekt, T. Kon. Ned. Aard. Gen., Leiden 1934

7G id., Fünf Sprachfamilien Südamerikas, Med. Kon. Ak. Wet. Lett. 77A5, Amsterdam 1935.

8G Nouvel examen des langues des Antilles avec notes sur les langues Arawak-Maipures et Caribes et vocabulaires Shebayo et Guayana (Guyana), J. Soc. Amér., Paris 1939. *Bij primitieve volken. De Gids, Amsterdam 1939.

Gus Die Feuerland-Indianer, Wien-Mödling 1931-7.

R. Harcourt, A relation of the voyage to Guiana, Hakluyt Soc. 2LX.

J. J. Hartsinck, Beschrijving van Guiana, Amsterdam 1770 .

J. A. van Heuvel, El Dorado, New York (1844).

$\mathrm{Iz}$

K. G. Izikowitz, Musical and other sound instruments of the South American Indians, Göteborg 1935.

* Morton C. Kahn, A tuberculin survey of the upper Aucaner Bush Negroes in Dutch Guiana, The Amer. J. of Hygiene, vol. 24, 1936.

C. C. Käyser, Verslag der Corantijn-expeditie, T. Kon. Ned. Aardr. Gen., Leiden 1912.

1Kar R. Karsten, The civilization of the South American Indians, London 1926.

2Kar id., Indian tribes of the Argentine and Bolivian Chaco, Helsingfors 1932 .

3Kar id., The head-hunters of Western Amazonas, Helsingfors 1935.

Ch. Kingsley, At last; a Christmas in the West Indies, London 1880.

$\mathrm{Kr} \quad$ W. Krickeberg, Märchen der Azteken und Inkaperuaner, Maya und Muisca, Jena 1928.

1KG Zwei Jahre unter den Indianern, Berlin 1909-10.

$2 \mathrm{KG}$

$3 \mathrm{KG}$

$4 \mathrm{KG}$ id., Vom Roroima zum Orinoco, Berlin-Stuttgart 1916-28. Indianermärchen aus Südamerika, Jena 1920.

Die Hianákoto-Umáua, Anthropos III,, Wien 1908.

J. Lombard, Recherches sur les tribus indiennes qui occupaient 1e territoire de la Guyane française vers 1730, J. Soc. Amér., Paris 1928.

C. Loukotka, Clasificación de las lenguas sudamericanas, Praha 1935.

*A. J. H. van Lynden, Op zoek naar de Zuidgrens, T. Kon. Ned. Aardr. Gen., Leiden 1939.

G. Marcel, L'apparition cartographique des monts TumucHumac, J. Soc. Amér., Paris 1897-8.

C. F. P. von Martius, Beiträge zur Ethnographie und Sprachenkunde Amerika's zumal Brasiliens, Leipzig 1867. 
Pierre Martyr Anghiera, De Orbe Novo, Paris 1907 (1e uitg. 16e eeuw).

Metr A. Métraux, La religion des Tupinamba, Paris 1928.

Nord E. Nordenskiöld, Faiseurs de miracles et voyants chez les Indiens Cuna, Rev. Int. Etn. Tucuman, 1932.

*G. Normand, Au pays de l'or, Paris 1924.

1 Nim C. Nimuendajú, Religion der Apapocúva-Guaraní, Z. f. Ethn., Berlin 1914.

2Nim id., Sagen der Tembé-Indianer, Z. f. Ethn., Berlin 1915.

$3 \mathrm{Nim}$ id., Bruchstücke Religion u. Ueberl. Sipaya-Ind., Anthropos 1919-22.

4Nim id., Die Palikur-Indianer, Göteborg 1926.

meP F. P. en A. P. Penard, De menschetende aanbidders der zonneslang, Paramaribo 1907-8.

perP Iets over onzen Caraïbischen Pujai, De Periskoop, Paramaribo 1925-26.

pP Het pujai-geheim der Surinaamsche Caraiben, Bijdr.Taal-, Land- en Volkenkunde van N.-I. 84, 's-Gravenhage 1928. K. Th. Preuss, Religion und Mythologie der Uitoto, Göttingen/Leipzig 1921.

Racc Raccolta di documenti e studi pubblicati dalla R. Commissione Colombiana, Roma 1892, Parte I Vol. I.

1Roth W. F. Roth, An enquiry animism folklore Guiana Indians, 30th ann. rep. Bureau Amer. Ethn., Washington 1915 .

2Roth id., An introductory study arts etc. id.; 38th ann. rep., W. 1924.

3Roth id., Additional studies arts etc. id. Bulletin 91, W. 1929.

SK ***Schulz-Kampfhenkel, Rätsel der Urwaldhölle, Berlin 1938.

Sp **F. Speiser, Im Düster des brasilianischen Urwaldes, Stuttgart 1926.

1Str E. Stradelli, Leggenda dell' Jurupary, Boll. Soc. geogr. Ital., Roma 1890.

2Str id., Vocabulario Nheêngatu, Rev. Inst. hist. geogr. Bras., Rio de Janeiro 1929.

Tat P. C. Tatevin, La langue Tapihïya, Wien 1910.

Te G. Tessmann, Die Indianer Nordost-Perus, Hamburg 1930.

*G. Versteeg, Op expeditie in Suriname, Elseviers Geill. Maandschrift 1905.

Vi M. de Villiers, Journal inédit du voyage du sergent La Haye de Cayenne aux chutes du Yari 1728-1729, J. Soc. Amér. Paris 1920.

H. Wassén, a) The Frog-Motive among the South American Indians, b) The Frog in Indian Mythology and Imaginative World, Anthropos XXIX, 1934. 